\title{
Comparison of Minimally Invasive Inductively Coupled Plasma- Mass Spectrometry Approaches for Strontium Isotopic Analysis of Medieval Stained Glass with Elevated Rubidium and Rare-Earth Element Concentrations
}

\author{
Alicia Van Ham-Meert,* Eduardo Bolea-Fernandez, Joke Belza, Dan Bevan, Klaus Peter Jochum, \\ Brigitte Neuray, Brigitte Stoll, Frank Vanhaecke, and Line Van Wersch
}

Cite This: ACS Omega 2021, 6, 18110-18122

Read Online

ACCESS | Lill Metrics \& More | 国 Article Recommendations ｜ＳＳ Supporting Information

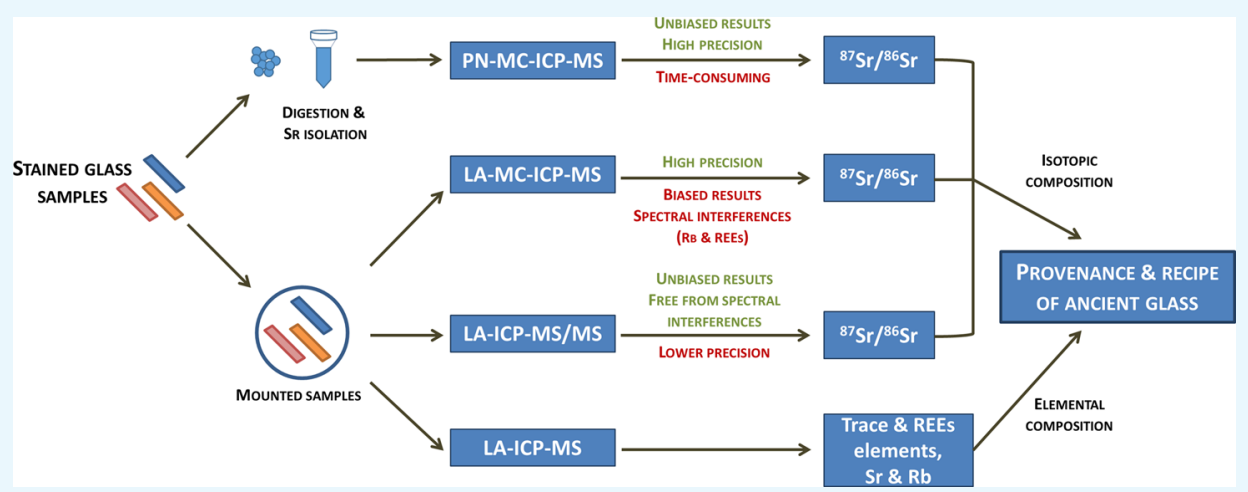

ABSTRACT: Different approaches for the determination of the ${ }^{87} \mathrm{Sr} /{ }^{86} \mathrm{Sr}$ isotope ratio of high-Rb glass are compared in this work to assess the suitability of minimally invasive approaches for applications on medieval stained glass (from the ancient Abbey of Stavelot in Belgium). It was found that pneumatic nebulization multicollector inductively coupled plasma-mass spectrometry (PNMC-ICP-MS) after acid digestion and chromatographic isolation of the target analyte out of the sample matrix can still be seen as the preferred method for the high-precision isotopic analysis of $\mathrm{Sr}$ in glass with high $\mathrm{Rb}$ and rare-earth element (REE) concentrations. Alternatively, the use of laser ablation (LA) for sample introduction is a powerful technique for the direct analysis of solid samples. However, both the high $\mathrm{Rb} / \mathrm{Sr}$ ratios in the samples of interest and the presence of REEs at sufficiently high concentrations lead to a large bias in LA-MC-ICP-MS, which cannot be corrected for, even by operating the MC-ICP-MS instrument at higher mass resolution and/or using mathematical corrections. It was demonstrated that LA tandem-ICP-MS (LAICP-MS/MS) using $\mathrm{CH}_{3} \mathrm{~F} / \mathrm{He}$ as the reaction gas to overcome spectral overlap in a mass-shift approach (chemical resolution) provides a viable alternative when (quasi) nondestructive analysis is required. This approach relies on the monitoring of $\mathrm{Sr}^{+}(\mathrm{m} / z=$ 86,87 , and 88 ) ions as the corresponding $\mathrm{SrF}^{+}$reaction product ions $(\mathrm{m} / z=105,106$, and 107), thus avoiding the occurrence of spectral interference. Self-evidently, the isotope ratio precision attainable using sequential quadrupole-based ICP-MS instrumentation ( $0.3 \% \mathrm{RSD})$ was found to be significantly worse than that of high-precision MC-ICP-MS (0.03\% RSD) with simultaneous detection, although it was still fit for the purpose of current applications. In addition to Sr isotopic analysis, the REE patterns and their potential influence on the Sr isotopic composition were evaluated by LA-ICP-MS.

\section{INTRODUCTION}

In the early medieval period (9th century onward), a new glass recipe spread in Western Europe based on the mixture of a silica source (usually ground quartz or a lime-poor sand) and ash from wood. ${ }^{1,2}$ The glass assemblage under consideration in this work originates from excavations at the Abbey of Stavelot in Belgium. The determination of the elemental and isotopic $(\mathrm{Sr}, \mathrm{Nd}$, and $\mathrm{Pb})$ composition of ancient glass is useful to understand glass manufacturing and the origin of raw materials. Previous chemical analysis on this assemblage was performed by particle-induced X-ray emission spectrometry/particleinduced $\gamma$-ray emission spectrometry (PIXE-PIGE). These analyses confirmed the recipe used for the glass as well as the

Received: April 12, 2021

Accepted: June 2, 2021

Published: July 9, 2021 
colorant used for different colors. ${ }^{1}$ In order to contribute to the elucidation of the source of ash and sand used for producing wood ash glass from Stavelot, accurate $\mathrm{Sr}$ isotopic compositions and rare-earth element (REE) concentrations need to be determined. Sr isotopes allow for tracing the calcium source (in this case, ash), whereas the REEs enter the glass with the silica source. Therefore, laser ablationinductively coupled plasma-mass spectrometry (LA-ICPMS) was carried out for minor and trace elemental analysis prior to $\mathrm{Sr}$ isotopic analysis using different ICP-MS approaches.

However, obtaining the $\mathrm{Sr}$ isotopic composition of a glass sample in a minimally invasive way can be challenging because of elevated REE and $\mathrm{Rb}$ concentrations, leading to spectral interferences from doubly charged REEs on different $\mathrm{Sr}$ isotopes and from the isobaric overlap of ${ }^{87} \mathrm{Rb}$ and ${ }^{87} \mathrm{Sr}$. This encouraged us to explore different approaches for measuring the $\mathrm{Sr}$ isotopic composition of glass samples with these particular characteristics. First, pneumatic nebulization (PN)multicollector (MC) ICP-MS analysis, following acid digestion and chromatographic isolation, which is the most commonly used method for high-precision isotopic analysis of $\mathrm{Sr}$, was relied on to provide reference values. Next, the possibility of using LA-MC-ICP-MS analysis, which was shown to be a reliable alternative for glasses with a low $\mathrm{Rb} / \mathrm{Sr}$ ratio, ${ }^{3}$ was evaluated. Finally, LA-ICP-MS/MS was assessed, as with this approach, spectral interferences from $\mathrm{Rb}$ and REEs can be avoided by double mass selection (MS/MS mode) and chemical resolution based on the use of a $\mathrm{CH}_{3} \mathrm{~F} / \mathrm{He}$ gas mixture, as demonstrated in previous studies. ${ }^{4,5}$ In this approach, a mass shift is achieved by a selective reaction between the $\mathrm{Sr}^{+}$ions and the reaction gas $\mathrm{CH}_{3} \mathrm{~F}\left(\mathrm{CH}_{3} \mathrm{~F} / \mathrm{He}\right.$ mixture), thus permitting interference-free monitoring of the $\mathrm{SrF}^{+}$reaction product ions. The present work evaluates the capabilities and limitations of different ICP-MS approaches aiming at an accurate and precise $\mathrm{Sr}$ isotopic analysis for specific applications in provenancing glass.

1.1. Strontium Isotopic Analysis by ICP-MS. Sr has four stable isotopes with their corresponding natural abundances: ${ }^{84} \mathrm{Sr}(0.56 \%),{ }^{86} \mathrm{Sr}(9.86 \%),{ }^{87} \mathrm{Sr}(7.0 \%)$, and ${ }^{88} \mathrm{Sr}(82.58 \%)$. As all elements with $\geq 2$ isotopes, $\mathrm{Sr}$ shows natural variations in its isotopic composition as a result of isotope fractionation. However, the main process responsible for the variation in the isotopic composition of $\mathrm{Sr}$ is the $\beta^{-}$decay of ${ }^{87} \mathrm{Rb}$ into ${ }^{87} \mathrm{Sr}$ $\left(T_{1 / 2}=4.96 \times 10^{10}\right.$ years $)$. As a result, the higher the initial ratio of $\mathrm{Rb}$ to $\mathrm{Sr}$, the more it will be enriched in ${ }^{87} \mathrm{Sr}$. The extent of this enrichment also depends on the time that both elements have resided together in a closed system. Hence, the isotope ratio of interest is ${ }^{87} \mathrm{Sr} /{ }^{86} \mathrm{Sr}$.

The ${ }^{87} \mathrm{Sr} /{ }^{86} \mathrm{Sr}$ ratio of a tree mostly reflects the bioavailable $\mathrm{Sr}$ in the soil. As the major and minor elemental composition of wood ash glass can vary because of the use of different tree species, specific parts of the tree used, felling season and/or growing location, $^{6-8}$ the elemental composition is an unreliable indicator of the origin of the ash. Sr isotopic analysis, on the other hand, has proven successful in provenancing trees from ancient buildings. ${ }^{9}$ As ash is the main $\mathrm{Sr}$ source in wood ash glass, the $\mathrm{Sr}$ isotopic composition $\left({ }^{87} \mathrm{Sr} /{ }^{86} \mathrm{Sr}\right.$ isotope ratio) serves as a tracer for wood used in the production of ash, similar to the ash of halophytic plants in plant ash glass. ${ }^{10,11}$

ICP-MS is one of the most powerful techniques for (ultra)trace elemental and isotopic analysis. However, obtaining accurate and precise ${ }^{87} \mathrm{Sr} /{ }^{86} \mathrm{Sr}$ isotope ratios using ICP-MS instrumentation still remains challenging. This is due to the occurrence of the spectral overlap between the signals of the target nuclides and those of isobaric, polyatomic, and/or doubly charged interfering ions, thus requiring a strategy to overcome these spectral interferences.

For $\mathrm{Sr}$ isotopic analysis, interference from doubly charged heavy REEs, polyatomic ions (e.g., $\mathrm{ArCa}^{+}$and $\mathrm{Ca}_{2}^{+}$), and isobaric nuclides $\left({ }^{87} \mathrm{Rb}\right)$ can seriously hamper accurate $\mathrm{Sr}$ isotope ratio measurements. ${ }^{12-15}$ In general, different approaches and instrumental developments have been introduced over the years aiming at overcoming spectral overlap. These include the use of single-collector (SC) and/or MC high-resolution sector-field ICP-MS (HR-SF-ICP-MS) instrumentation and the use of quadrupole-based ICP-MS (ICP-QMS) instrumentation equipped with the collision/ reaction cell (CRC) technology. 4,16

The coincidence of ion signals from ${ }^{87} \mathrm{Rb}$ and ${ }^{87} \mathrm{Sr}$ is the hardest to resolve. The resolution $(\mathrm{m} / \Delta \mathrm{m})$ required to resolve this isobaric interference $\left(\mathrm{m}^{87} \mathrm{Rb}=86.909181 \mathrm{~g} / \mathrm{mol}\right.$ and $\mathrm{m}^{87} \mathrm{Sr}=86.908878 \mathrm{~g} / \mathrm{mol}$ ) is approximately 290,000 , which is beyond the capabilities of the present-day high-resolution ICPMS instrumentation. ${ }^{17,4}$ For low $\mathrm{Rb} / \mathrm{Sr}$ ratios, this interference can be mathematically corrected by monitoring ${ }^{85} \mathrm{Rb}$ and taking into account the natural isotopic abundances of both $\mathrm{Rb}$ isotopes; however, once the $\mathrm{Rb}$ to $\mathrm{Sr}$ concentration ratio exceeds $14 \%$, this correction introduces a significant bias in the ${ }^{87} \mathrm{Sr} /{ }^{86} \mathrm{Sr}$ isotope ratio results. ${ }^{10}$ Therefore, chromatographic isolation is often used prior to $\mathrm{Sr}$ isotopic analysis using highprecision PN-MC-ICP-MS, in addition to the mathematical correction mentioned above. Although this is a routinely used approach, the complete mineralization of some sample types is laborious and time-consuming and requires the use of hazardous reagents, while incomplete sample digestion could lead to inaccuracy because of isotope fractionation. Furthermore, spatially resolved information cannot be achieved in the "solution-mode." Finally, especially in the case of cultural heritage materials, minimally invasive sampling is preferred to preserve the samples. To overcome these limitations, direct solid sampling using state-of-the-art laser ablation (LA) can be used as a means of sample introduction. LA-MC-ICP-MS was found to be a suitable approach for high-precision isotopic analysis of $\mathrm{Sr}$ in solid samples with low $\mathrm{Rb} / \mathrm{Sr}$ ratios, but precise and unbiased isotope ratio results are unattainable for high $\mathrm{Rb} / \mathrm{Sr}$ ratios without a robust approach to correct for $\mathrm{Rb}$ mass discrimination during LA-MC-ICP-MS measurements. ${ }^{18}$ Alternatively, to overcome spectral overlap when relying on LA for sample introduction, chemical resolution can be performed using ICP-CRC-QMS (inductively coupled plasma-collision/ reaction cell-quadrupole mass spectrometry) instrumentation.

This method relies on the selective reaction between the interfering ion and the reaction gas (on-mass approach) or the analyte ion and the reaction gas (mass-shift approach). ${ }^{16,19}$ It has been shown that $\mathrm{Sr}^{+}$ions react with $\mathrm{CH}_{3} \mathrm{~F}$, forming $\mathrm{SrF}^{+}$ reaction product ions that can be measured free from spectral interferences at a different mass-to-charge $(\mathrm{m} / z)$ ratio $(+19$ $\mathrm{amu}$ ), whereas $\mathrm{Rb}^{+}$does not react with $\mathrm{CH}_{3} \mathrm{~F} .{ }^{17}$ An additional advantage of selective fluorination is the monoisotopic character of fluorine, thus preserving the original isotopic pattern. Although this work was found to be promising, only close matrix-matching of the standard used to correct for mass discrimination provided accurate $\mathrm{Sr}$ isotope ratio results when using traditional single-quadrupole (SQ) ICP-MS instrumen- 


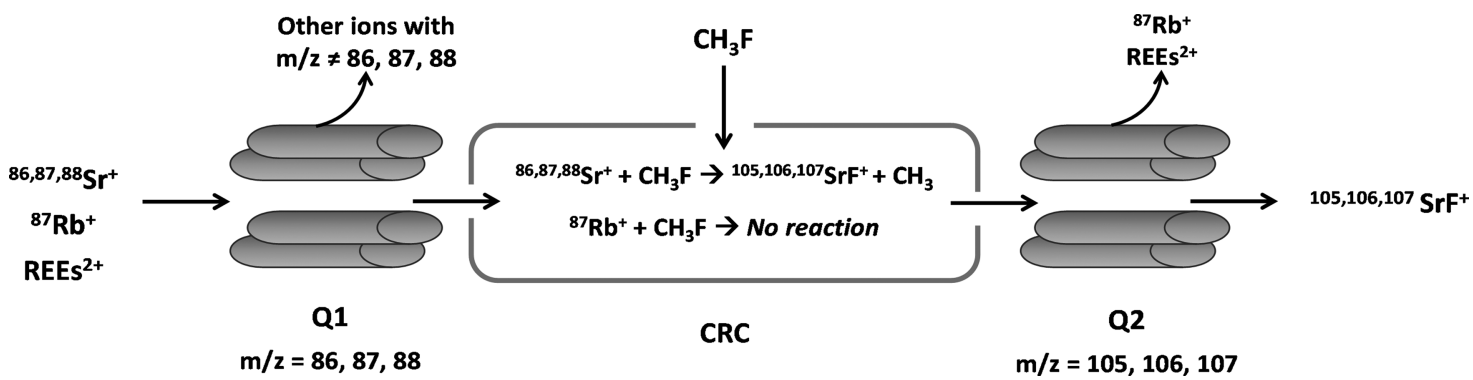

Figure 1. Operating principles of ICP-MS/MS and chemical resolution to overcome spectral interferences in the isotopic analysis of $\mathrm{Sr}_{\mathrm{s}} \mathrm{using} \mathrm{CH}_{3} \mathrm{~F}$ as the reaction gas in a mass-shift approach.

Table 1. PIXE/PIGE Major and Minor Elemental Composition $(\% \mathrm{~m} / \mathrm{m})$ of 12 Glasses from Stavelot ${ }^{a, b}$

\begin{tabular}{|c|c|c|c|c|c|c|c|c|c|c|c|c|}
\hline $\begin{array}{l}\text { sample } \\
\text { ID }\end{array}$ & $\begin{array}{l}\text { ST } 1278 \\
\text { ambre }\end{array}$ & $\begin{array}{c}\text { ST } 1278 \\
\text { I2 }\end{array}$ & $\begin{array}{c}\text { ST } 1278 \\
\text { I3 }\end{array}$ & $\begin{array}{c}\text { ST } 1371 \\
\text { I1 }\end{array}$ & $\begin{array}{c}\text { ST } 1371 \\
\text { I2 }\end{array}$ & $\begin{array}{c}\text { ST } 1278 \\
\text { I1 }\end{array}$ & $\begin{array}{l}\text { ST } 1371 \\
\text { rose }\end{array}$ & $\begin{array}{l}\text { ST } 1371 \\
\text { rouge }\end{array}$ & $\begin{array}{c}\text { ST } 1371 \\
\text { V1 }\end{array}$ & $\begin{array}{c}\text { ST } 1278 \\
\text { V1 }\end{array}$ & $\begin{array}{c}\text { ST } 1371 \\
\text { V2 }\end{array}$ & $\begin{array}{c}\text { ST } 1278 \\
\text { V2 }\end{array}$ \\
\hline color & amber & natural & natural & natural & natural & natural & pink & red & green & green & green & green \\
\hline $\mathrm{Na}_{2} \mathrm{O}$ & 2.91 & 1.04 & 1.11 & 0.74 & 1.05 & 0.8 & 0.97 & 0.71 & 0.91 & 0.79 & 0.74 & 0.73 \\
\hline $\mathrm{MgO}$ & 6.43 & 5.21 & 5.14 & 4.5 & 4.82 & 4.29 & 5.43 & 4.08 & 3.94 & 4.5 & 3.99 & 4.04 \\
\hline $\mathrm{Al}_{2} \mathrm{O}_{3}$ & 0.92 & 1.16 & 1.16 & 1.84 & 1.56 & 1.81 & 1.11 & 1.15 & 1.33 & 1.08 & 1.12 & 1.39 \\
\hline $\mathrm{SiO}_{2}$ & 53.67 & 57.82 & 56.26 & 56 & 55.11 & 54.16 & 52.25 & 52.23 & 51.85 & 53.87 & 53.02 & 52.49 \\
\hline $\mathrm{P}_{2} \mathrm{O}_{5}$ & 3.17 & 4.26 & 4.73 & 4.93 & 4.31 & 3.2 & 5.73 & 4.33 & 4.67 & 4.33 & 4.59 & 2.7 \\
\hline $\mathrm{SO}_{3}$ & 0.13 & 0.09 & 0.09 & 0.22 & 0.18 & 0.33 & 0.07 & 0.25 & 0.22 & 0.14 & 0.2 & 0.21 \\
\hline $\mathrm{Cl}$ & 0.42 & 0.05 & 0.06 & 0.09 & 0.1 & 0.04 & 0.12 & 0.18 & 0.18 & 0.03 & 0.27 & 0.28 \\
\hline $\mathrm{K}_{2} \mathrm{O}$ & 13.56 & 9.2 & 9.73 & 11 & 11.82 & 14.55 & 10.89 & 16.94 & 16.78 & 10.14 & 14.42 & 20.21 \\
\hline $\mathrm{CaO}$ & 17.52 & 19.76 & 20.23 & 18.85 & 19.32 & 17.72 & 21.9 & 17.83 & 16.36 & 21.36 & 17.98 & 13.84 \\
\hline $\mathrm{TiO}_{2}$ & 0.08 & 0.14 & 0.12 & 0.18 & 0.15 & 0.15 & 0.13 & 0.11 & 0.14 & 0.11 & 0.14 & 0.11 \\
\hline $\mathrm{MnO}$ & 0.45 & 0.47 & 0.49 & 0.56 & 0.64 & 1.42 & 0.48 & 0.34 & 0.43 & 0.51 & 0.58 & 1.06 \\
\hline $\mathrm{Fe}_{2} \mathrm{O}_{3}$ & 0.34 & 0.49 & 0.52 & 0.6 & 0.61 & 0.68 & 0.48 & 0.8 & 0.48 & 0.49 & 0.44 & 0.38 \\
\hline $\mathrm{Cu}_{2} \mathrm{O}$ & 0.03 & 0.1 & 0.16 & 0.13 & 0.05 & 0.02 & 0.03 & 0.5 & 1.87 & 1.89 & 2.2 & 1.36 \\
\hline $\mathrm{NiO}$ & 0 & 0 & 0 & 0 & 0 & 0.01 & 0 & 0 & 0 & 0 & 0 & 0.01 \\
\hline $\mathrm{ZnO}$ & 0.04 & 0.04 & 0.04 & 0.05 & 0.04 & 0.04 & 0.03 & 0.19 & 0.49 & 0.31 & 0.03 & 0.44 \\
\hline $\mathrm{As}_{2} \mathrm{O}_{5}$ & 0 & 0 & 0 & 0 & 0 & 0 & 0 & 0 & 0 & 0.01 & 0 & 0 \\
\hline $\mathrm{Rb}_{2} \mathrm{O}$ & 0.03 & 0.02 & 0.02 & 0.02 & 0.01 & 0.03 & 0.03 & 0.02 & 0.02 & 0.01 & 0.02 & 0.03 \\
\hline $\mathrm{SrO}$ & 0.05 & 0.05 & 0.05 & 0.05 & 0.05 & 0.09 & 0.05 & 0.04 & 0.04 & 0.04 & 0.04 & 0.06 \\
\hline $\mathrm{ZrO}_{2}$ & 0.02 & 0.02 & 0.02 & 0.03 & 0.02 & 0.02 & 0.02 & 0.02 & 0.02 & 0.02 & 0.02 & 0.02 \\
\hline $\mathrm{SnO}_{2}$ & 0.01 & 0.01 & 0.01 & 0.02 & 0.01 & 0.02 & 0 & 0.04 & 0.03 & 0.25 & 0 & 0.05 \\
\hline $\mathrm{Sb}_{2} \mathrm{O}_{5}$ & 0.01 & 0 & 0 & 0 & 0 & 0 & 0.01 & 0.02 & 0.02 & 0.02 & 0 & 0 \\
\hline $\mathrm{BaO}$ & 0.2 & 0.09 & 0.06 & 0.15 & 0.16 & 0.6 & 0.26 & 0.2 & 0.1 & 0 & 0.15 & 0.56 \\
\hline $\mathrm{PbO}$ & 0 & 0.01 & 0 & 0.02 & 0 & 0 & 0 & 0.02 & 0.11 & 0.1 & 0.03 & 0.04 \\
\hline
\end{tabular}

${ }^{a}$ Co was measured, but not detected, so it is not included in the table. ${ }^{b}$ The only glass samples from the original assemblage that were not highly corroded turned out to be the natron glasses. They represent approximately $4 \%$ of the assemblage and were found in "secteur 2 and 3 " (see Figure S1 of the SI).

tation. $^{20}$ In recent years, this limitation was ascribed to $(i)$ the lack of control over the ion-molecule chemistry occurring within a pressurized multiple cell and (ii) the presence of new interferences at the $m / z$ ratio of the newly prepared reaction product ions when using SQ-ICP-MS instrumentation., ${ }^{4,5}$ These limitations can be avoided when using tandem ICPMS/MS. This type of instrumentation is based on the use of two quadrupole mass filters and a CRC located in between. As demonstrated in a significant number of recent publications, this double mass configuration (MS/MS mode) provides additional means to deal with spectral overlaps using chemical resolution in a more straightforward way ${ }^{4,5,21}$ (Figure 1). In the specific case of $\mathrm{Sr}$, at any given time, one mass-to-charge $(\mathrm{m} / z)$ ratio of interest $(84,86,87$, and 88$)$ is selected in the first quadrupole (Q1), and the $\mathrm{Sr}^{+}$atomic ions react with $\mathrm{CH}_{3} \mathrm{~F}$ gas, forming the corresponding reaction product ion $\left(\mathrm{SrF}^{+}\right)$. The second quadrupole is set at the mass-to-charge ratio of the corresponding newly formed molecular ion $(\mathrm{m} / z=$
$103,105,106$, and 107). It needs to be noted that the additional quadrupole located before the CRC filters out all ions with a different $m / z$ ratio, thus preventing the spectral overlap between the newly created reaction product ions and other concomitant matrix ions, such as ${ }^{103} \mathrm{Rh},{ }^{106} \mathrm{Cd},{ }^{105,106} \mathrm{Pd}$, or ${ }^{107} \mathrm{Ag}$. ${ }^{4,5}$ This mass-shift approach using $\mathrm{CH}_{3} \mathrm{~F}$ gas, and based on monitoring the $\mathrm{SrF}^{+}$reaction product ions, avoids the occurrence of other spectral interferences from polyatomic and/or doubly charged ions, thus, in theory, allowing precise and unbiased $\mathrm{Sr}$ isotope ratio results to be obtained without (i) the need for previous analyte/matrix separation or (ii) subsequent data treatment using mathematical interference corrections.

In this work, different types of ICP-MS instrumentation (MC-ICP-MS and ICP-MS/MS) and sample introduction approaches (solution-based and direct analysis of solid samples using LA) have been used for the determination of the $\mathrm{Sr}$ isotopic composition of medieval stained-glass windows. 
Solution-based PN-MC-ICP-MS analysis after the chromatographic isolation of the analyte out of the sample matrix can be considered as the reference technique. The aim of this work is to assess the performance of LA-MC-ICP-MS and LA-ICPMS/MS for obtaining precise and unbiased $\mathrm{Sr}$ isotope ratio results in the presence of $\mathrm{Rb}$ at different $\mathrm{Rb} / \mathrm{Sr}$ elemental ratios and of other potential interferences, caused by the REEs, as alternative techniques for the isotopic analysis of $\mathrm{Sr}$ in medieval stained glass. The elemental composition determined through LA-ICP-MS allows quantifying the potential interferences (REEs and $\mathrm{Rb}$ ).

\section{MATERIALS}

2.1. Reference Materials. 2.1.1. Trace Element Analysis. NIST SRM 610 (National Institute of Standards and Technology, USA) and USGS GSE-1G (United States Geological Survey) were used for determining the response factors (see 3.1.). Corning D (a glass produced by the Corning museum of glass to mimic natron glass) was used as the secondary reference material, and KL-2G (an MPI-DING glass) and NIST SRM 612 were used as secondary reference materials for $\mathrm{QA} / \mathrm{QC}$.

2.1.2. $L A-M C-I C P-M S$ and LA-ICP-MS/MS Isotopic Analysis. For mass discrimination correction purposes, NIST SRM 610 was measured in a sample/standard bracketing (SSB) approach. Corning glass D and archeological glass from Dibba in the United Arab Emirates (009.01.02) were also included in every analysis as secondary reference materials. ${ }^{3,22}$

For the CRMs and archeological samples, we worked with mounted sections of polished glass.

2.2. Archeological Materials. A total of 12 medieval stained-glass windows from "secteur 1" (see Figure 1 of the Supporting Information (SI) for a map of the archeological site of Stavelot) were analyzed in this work. Table 1 lists the samples with their sample number and color. All these glasses were highly altered. ${ }^{1}$ After excavation, they were kept in demineralized water and Cetavlon soap in a closed container until analysis. ${ }^{1,23}$

A close inspection of the glass assemblage showed that flat glass was obtained through blowing the glass in large cylindrical tubes that were cut open and unrolled.

Most glass samples are described as "colorless" (in reality, this means they are naturally colored; no colorant was deliberately added to them, but they have not been decolored either, so they have a greenish tint): STV99 1278 I1, STV99 1278 I2, STV99 1278 I3, STV99 1371 I1, and STV99 1371 I2. The second most represented color is green (intentionally colored with copper): STV99 1278 V1, STV99 1278 V2, STV99 $1371 \mathrm{V1}$, and STV99 $1371 \mathrm{~V} 2 .^{1}$ Also, there are red (STV99 1371 rouge), pink (STV99 1371 red), and ambercolored (STV99 1278 amber) glass samples. The major and minor elemental composition was previously determined by particle-induced X-ray emission spectrometry/particle-induced $\gamma$-ray emission spectrometry (PIXE-PIGE) via analysis on freshly polished breaks, and the results are also included in Table $1{ }^{1}$

The PIXE/PIGE analysis showed a narrow distribution of alumina, titanium dioxide, and iron oxide concentrations. This leads to the conclusion that only a single source of silica was used for high-potassium glasses from Stavelot. ${ }^{1}$ The potassium, calcium and magnesium concentrations were found to be significantly variable. This indicates that either the use of different pretreatments or different origins of the ashes, that is, tree species, part of the tree, and felling season, can affect the final composition of the ash. ${ }^{1,8}$ The secure context and dating of the glass (all from the same destruction layer) also disproves the earlier hypothesis of Wedepohl et al. $(2011)^{2}$ that different potassium contents in the glass represent a chronological evolution. ${ }^{1}$

\section{METHODS}

3.1. LA-ICP-MS: Elemental Analysis. Elemental analyses of the archeological glass were carried out at the Max Planck Institute for Chemistry in Mainz, Germany. A New Wave UP213 solid state LA unit fitted with a $255 \mathrm{~cm}^{2}$ large-format cell was coupled to a Thermo Finnigan Element 2 sector-field ICPMS instrument. The instrument settings of the LA and ICPMS units were tuned daily for high signal intensity (based on ${ }^{146} \mathrm{Nd}^{+},{ }^{232} \mathrm{Th}^{+}$, and ${ }^{238} \mathrm{U}^{+}$), low oxide formation based on ${ }^{232} \mathrm{Th}^{16} \mathrm{O}^{+} /{ }^{232} \mathrm{Th}^{+}<1 \%$, and low laser-induced elemental fractionation by verifying that ${ }^{238} \mathrm{U}^{+} /{ }^{232} \mathrm{Th}^{+} \approx 1$ during ablation of a NIST SRM 612-glass-certified reference material. Three replicate spot measurements of $60 \mathrm{~s}$ were performed after a short preablation to remove any surface contamination. A few seconds of gas blank were measured before each sample for background subtraction. The first values obtained during ablation were not used in further data processing to reduce the potential influence of surface contamination. Instrument settings and measurement conditions are included in Table 2. The measurements were performed in a combined B-scan

Table 2. Measurement Parameters for LA-ICP-MS, PN-MCICP-MS, LA-MC-ICP-MS, and LA-ICP-MS/MS

\begin{tabular}{|c|c|c|c|c|c|}
\hline & $\begin{array}{l}\text { LA- } \\
\text { ICP- } \\
\text { MS }\end{array}$ & $\begin{array}{l}\text { PN-MC- } \\
\text { ICP-MS }\end{array}$ & LA-MC-I & P-MS & $\begin{array}{l}\text { LA-ICP- } \\
\text { MS/MS }\end{array}$ \\
\hline & & & preablation & ablation & \\
\hline fluence $\left(\mathrm{J} / \mathrm{cm}^{2}\right)$ & $\begin{array}{r}13.1- \\
14.1\end{array}$ & & 0.51 & 4.05 & 2.9 \\
\hline spot size $(\mu \mathrm{m})$ & 100 & & 150 & $\begin{array}{l}80- \\
120\end{array}$ & $20-35$ \\
\hline frequency $(\mathrm{Hz})$ & 10 & & 30 & $20-50$ & $30-50$ \\
\hline $\begin{array}{c}\text { scan speed }(\mu \mathrm{m} / \\
\mathrm{s})\end{array}$ & & & 500 & 13 & 10 \\
\hline $\begin{array}{l}\text { He carrier gas } \\
\text { laser }(1 / \mathrm{min})\end{array}$ & 0.65 & & 0.5 & 0.5 & 0.5 \\
\hline $\begin{array}{l}\text { measurement } \\
\text { time }(\mathrm{s})\end{array}$ & 60 & 60 & & 60 & 60 \\
\hline $\begin{array}{l}\text { cooling gas (1/ } \\
\min )\end{array}$ & 15 & 15 & & 15 & 15 \\
\hline $\begin{array}{l}\text { auxiliary gas (1/ } \\
\text { min) }\end{array}$ & 0.87 & 0.85 & & 0.75 & 1 \\
\hline $\begin{array}{l}\text { sample gas (1/ } \\
\text { min) }\end{array}$ & 0.6 & 0.85 & & 0.909 & 1.02 \\
\hline RF power & 1270 & 1200 & & 1350 & 1550 \\
\hline
\end{tabular}

and E-scan mode; the dwell time for each mass was $7.5 \mathrm{~ms}$, and the following masses were monitored: ${ }^{13} \mathrm{C},{ }^{7} \mathrm{Li},{ }^{11} \mathrm{~B},{ }^{23} \mathrm{Na}$, ${ }^{25} \mathrm{Mg},{ }^{27} \mathrm{Al},{ }^{29} \mathrm{Si},{ }^{31} \mathrm{P},{ }^{34} \mathrm{~S},{ }^{39} \mathrm{~K},{ }^{43} \mathrm{Ca},{ }^{49} \mathrm{Ti},{ }^{51} \mathrm{~V},{ }^{53} \mathrm{Cr},{ }^{55} \mathrm{Mn},{ }^{57} \mathrm{Fe}$, ${ }^{65} \mathrm{Cu},{ }^{66} \mathrm{Zn}$ (LR), ${ }^{67} \mathrm{Zn},{ }^{75} \mathrm{As},{ }^{85} \mathrm{Rb},{ }^{86} \mathrm{Sr},{ }^{87} \mathrm{Sr},{ }^{88} \mathrm{Sr}$ (LR), ${ }^{90} \mathrm{Zr}$, ${ }^{93} \mathrm{Nb},{ }^{95} \mathrm{Mo},{ }^{111} \mathrm{Cd},{ }^{118} \mathrm{Sn},{ }^{121} \mathrm{Sb},{ }^{133} \mathrm{Cs},{ }^{137} \mathrm{Ba}$ (LR), ${ }^{139} \mathrm{La}$ (LR), ${ }^{140} \mathrm{Ce}$ (LR), ${ }^{141} \mathrm{Pr},{ }^{146} \mathrm{Nd},{ }^{147} \mathrm{Sm},{ }^{151} \mathrm{Eu},{ }^{157} \mathrm{Gd},{ }^{159} \mathrm{~Tb},{ }^{163} \mathrm{Dy}$, ${ }^{165} \mathrm{Ho},{ }^{167} \mathrm{Er},{ }^{169} \mathrm{Tm},{ }^{173} \mathrm{Yb},{ }^{175} \mathrm{Lu},{ }^{178} \mathrm{Hf},{ }^{181} \mathrm{Ta},{ }^{203} \mathrm{Tl},{ }^{208} \mathrm{~Pb}$ (LR), ${ }^{209} \mathrm{Bi},{ }^{232} \mathrm{Th},{ }^{238} \mathrm{U}$.

The elemental composition was calculated following the method proposed by Gratuze et al. (2001). ${ }^{24}$ Using reference 
materials NIST SRM 610 and GSE-1G glasses, response factors $\left(k_{\mathrm{j}}\right)$ are determined for each element $(j)$ as follows:

$$
k_{j}=\frac{\text { counts }_{\mathrm{j}}}{\text { counts }_{\mathrm{IS}}} \times \frac{\text { concentration }_{\mathrm{IS}}}{\text { concentration }_{\mathrm{j}}}
$$

The average response factor was used for the calculations. The concentration of element " $j$ " in sample " $i$ " is then calculated as follows:

$$
\text { Concentration }_{\mathrm{ij}}=\frac{\text { counts }_{\mathrm{ij}}}{\text { counts }_{\mathrm{iS}} \times \mathrm{k}_{\mathrm{j}}} \times \text { concentration }_{\mathrm{iIS}}
$$

In order to determine the concentration of an element, the concentration of the internal standard should be known. In this case, the internal standard is calcium (Ca), the concentration of which was determined by PIXE/PIGE. ${ }^{1}$ This means, of course, that the quality of the final elemental data depends on the quality of the PIXE/PIGE analysis.

3.2. PN-MC-ICP-MS. Around $70 \mathrm{mg}$ of not visibly altered glass was ground in an agate mortar, accurately weighed on an analytical balance, and subsequently dissolved using a four-acid dissolution protocol (Table 3). Sr was isolated from the matrix

Table 3. Dissolution Procedure for the PN-MC-ICP-MS

\begin{tabular}{|c|c|c|c|c|}
\hline acid & $T\left({ }^{\circ} \mathrm{C}\right)$ & $\mathrm{t}(\mathrm{h})$ & $T_{\text {evaporation }}\left({ }^{\circ} \mathrm{C}\right)$ & $t_{\text {evaporation }}(\mathrm{h})$ \\
\hline $3 \mathrm{~mL} 14 \mathrm{M} \mathrm{HNO}_{3}$ & 200 & 1 & 200 & 4 \\
\hline $1 \mathrm{~mL} \mathrm{HClO}_{4}$ & 200 & 0.5 & 240 & 1 \\
\hline $3 \mathrm{~mL} \mathrm{HF}$ & 90 & 13 & 180 & 4 \\
\hline $3 \mathrm{~mL}$ aqua regia & 200 & 1 & 200 & 4 \\
\hline
\end{tabular}
Analysis

using the Sr-Spec (Eichrom) resin, following the procedure described elsewhere. ${ }^{25}$ After isolation, the solution was diluted to a final concentration of $250 \mu \mathrm{g} / \mathrm{L}$ for the PN-MC-ICP-MS analysis. A Neptune MC-ICP-MS (ThermoScientific, Germany) was used to measure the isotopic composition. PN-MCICP-MS measurements were performed in low mass resolution; while the interface was equipped with an X-type $\mathrm{Ni}$ skimmer and a standard Ni sampling cone (1.1 and $0.8 \mathrm{~mm}$ aperture, respectively), 60 cycles of $1 \mathrm{~s}$ were measured for each sample. The autosampler is an ASX-100 from CETAC, the nebulizer is PFA 100, and the pump speed is $100 \mu \mathrm{L} / \mathrm{min}$. The $\mathrm{Sr}$ isotope ratio results were corrected for (remaining) isobaric interference from $\mathrm{Rb}$ and $\mathrm{Kr}$, while the bias introduced by instrumental mass discrimination was corrected by relying on the exponential law and considering the ${ }^{88} \mathrm{Sr} /{ }^{86} \mathrm{Sr}$ ratio as sufficiently constant in nature to correct the ${ }^{87} \mathrm{Sr} /{ }^{86} \mathrm{Sr}$ ratio.

The cup configuration is detailed in Table 4. Instrument settings were optimized for obtaining the highest signal-tobackground ratio for $\mathrm{Sr}$ monitoring.

3.3. LA-MC-ICP-MS. To avoid extensive sample pretreatments, LA was evaluated as a sample introduction approach for direct MC-ICP-MS Sr isotopic analysis of solid samples. In this context, the bias in the $\mathrm{Sr}$ isotope ratio results due to the high
$\mathrm{Rb} / \mathrm{Sr}$ ratio in the samples of interest was evaluated. For this purpose, the LA-MC-ICP-MS analysis was performed using the methodology developed in a previous work. ${ }^{3}$ A $193 \mathrm{~nm}$ ArF*excimer-based LA unit (Analyte G2, Teledyne CETAC Technologies, USA) was coupled to an MC-ICP-MS unit (ThermoScientific Neptune, Germany). Prior to introduction into the ICP, the helium carrier gas transporting the ablated material was mixed with $0.011 \mathrm{~mL} / \mathrm{min} \mathrm{N}_{2}$ gas. The addition of $\mathrm{N}_{2}$ gas was performed to enhance sensitivity and smooth out fluctuations in the $\mathrm{Sr}^{+}$signals. ${ }^{26}$ The addition of $\mathrm{N}_{2}$ and the operation in dry plasma rather than in wet plasma conditions are the only two differences compared to the method developed in the previous work. ${ }^{3}$ The cup configuration is provided in Table 4, and the other instrument settings and measurement conditions are shown in Table 2. All measurements were performed in medium mass resolution (i.e., $\Delta \mathrm{m} / \mathrm{m}$ $=4000$ ), with an interface equipped with a Ni jet-sampling cone and a Ni X-type skimmer. ${ }^{3}$ Frequency and spot sizes were adapted for each sample to achieve similar signal intensities (within $\pm 10 \%$ ) for standards and samples, as required for an appropriate mass bias correction. Mass bias correction was performed as performed in PN-MC-ICP-MS.

3.4. LA-ICP-MS/MS: Sr Isotopic Analysis. A $193 \mathrm{~nm}$ ArF*excimer-based LA unit (Analyte G2, Teledyne CETAC Technologies, USA), equipped with a prototype of an inhouse-developed and recently commercialized ultrafast tubetype ablation chamber (Van Malderen et al., 2015), was coupled with an Agilent 8800 tandem ICP-MS instrument (ICP-QQQ Agilent Technologies, Japan). Aerosol was transported from the ablation site in the $\mathrm{He}$ carrier gas via polyetheretherketone (PEEK) tubing ( $1 \mathrm{~mm}$ internal diameter and $1.2 \mathrm{~m}$ length) and mixed with the Ar make-up gas in a glass mixing bulb, before entering a two-inlet Peltier-cooled Scott-type spray chamber, simultaneously introducing $0.28 \mathrm{M}$ $\mathrm{HNO}_{3}$ through a MicroMist nebulizer. This setup allows wet plasma conditions to be obtained, thus improving signal stability as a result of the mitigation of some variations caused by differences in plasma loading. ${ }^{3,4,26,27}$ The instrument was operated in the MS/MS mode with both quadrupoles used as mass filters (resolution $=1 \mathrm{amu}$ ). Data acquisition was performed in the time-resolved analysis (TRA) mode with a dwell time of $0.3 \mathrm{~s}$. The octopole CRC was pressurized with $2.3 \mathrm{~mL} / \mathrm{min}$ of a mixture of $\mathrm{CH}_{3} \mathrm{~F} / \mathrm{He}\left(10 \% \mathrm{CH}_{3} \mathrm{~F}\right.$ in $\mathrm{He}$, Air Liquide, Belgium). The instrument was tuned for a maximum $\mathrm{SrF}^{+}$signal intensity during the continuous ablation of the NIST SRM 610 reference material. For each sample, the signal intensity was matched to the signal intensity obtained for the bracketing standard (within $\pm 15 \%$ ) by varying the spot size and/or laser repetition rate.

The mass bias correction was performed in two steps: the first internal correction relying on the ${ }^{88} \mathrm{Sr} /{ }^{86} \mathrm{Sr}$ ratio to correct the ${ }^{87} \mathrm{Sr} /{ }^{86} \mathrm{Sr}$ ratio, followed by an external correction based on the use of NIST SRM 610, measured in a sample standard bracketing sequence.

\section{Table 4. Cup Configuration for the MC-ICP-MS Analysis}

\begin{tabular}{lcccccccc}
\multicolumn{1}{c}{ cup } & $\mathrm{L} 4$ & $\mathrm{~L} 3$ & $\mathrm{~L} 2$ & $\mathrm{~L} 1$ & $\mathrm{C}$ & $\mathrm{H} 1$ & $\mathrm{H} 2$ & $\mathrm{H} 3$ \\
$\begin{array}{l}\text { nuclide } \\
\text { isobaric interference }\end{array}$ & ${ }^{82} \mathrm{Kr}$ & ${ }^{83} \mathrm{Kr}$ & ${ }^{84} \mathrm{Sr}$ & ${ }^{85} \mathrm{Rb}$ & ${ }^{86} \mathrm{Sr}$ & ${ }^{87} \mathrm{Sr}$ & ${ }^{88} \mathrm{Sr}$ & ${ }^{89} \gamma$ \\
amplifier(10) $(\Omega)$ & 12 & 12 & 11 & 12 & 11 & ${ }^{87} \mathrm{Rb}$ & & \\
\end{tabular}


Table 5. Sr Isotopic Composition of the Samples from Stavelot Results from PN-MC-ICP-MS (the Data for NIST SRM 610 and Corning D in this Column Are Reference Values from Woodhead and Hergt, 2001 and Van Ham-Meert et al. 2018, Respectively), ${ }^{31,3}$ LA-MC-ICP-MS, and LA-ICP-MS/MS.

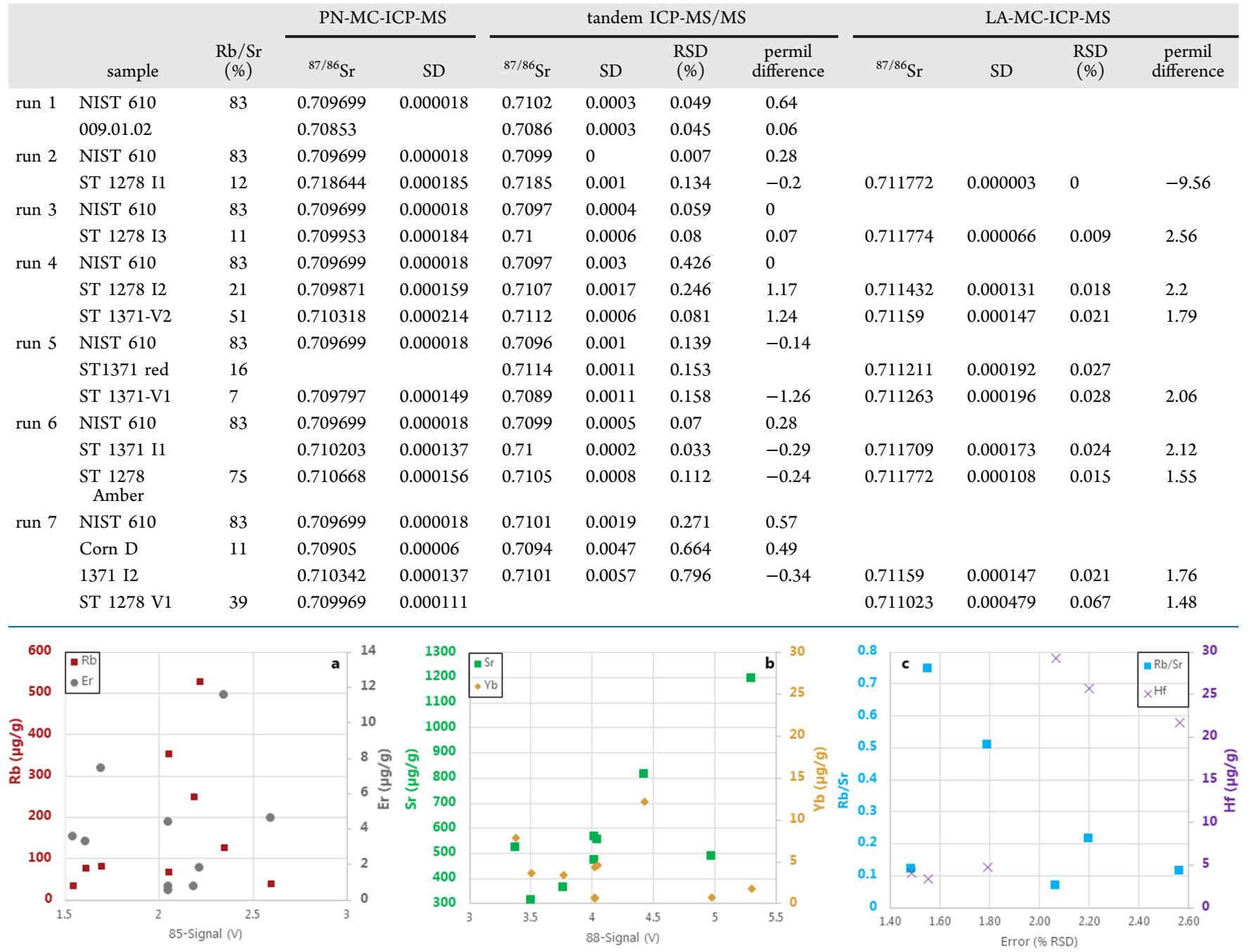

Figure 2. LA-MC-ICP-MS measurements a: influence of $\mathrm{Rb}$ and Er on the 85-signal; b: influence of the $\mathrm{Sr}$ and $\mathrm{Yb}$ concentrations on the 88-signal; $\mathrm{c}$ : influence of the $\mathrm{Rb} / \mathrm{Sr}$ ratio and $\mathrm{Hf}$ concentration on the error.

\section{RESULTS AND DISCUSSION}

In this section, the measurement uncertainty refers to 2 times the standard error (2 S.E.) within a run of a sample or standard. The bias is the difference in per mill (\%o) between a measured value and either a reference value or the PN-MCICP-MS results in case of archeological materials.

4.1. Evaluation of the Sr Isotopic Analysis Methods. 4.1.1. $P N-M C-I C P-M S$. As indicated in the previous section, PN-MC-ICP-MS provides precise and unbiased $\mathrm{Sr}$ isotope ratio results. For QA/QC, NIST SRM $987\left({ }^{87} \mathrm{Sr} /{ }^{86} \mathrm{Sr}=\right.$ 0.710248 - Weis et al., 2006) ${ }^{28}$ was measured after every sample, and a mean $\mathrm{Sr}$ isotopic composition of $0.71021 \pm$ 0.00002 was obtained for 18 measurements in this particular run. In this work, the results obtained using PN-MC-ICP-MS are used as reference values for comparison with the LA-MCICP-MS and LA-ICP-MS/MS results (see Sections 4.1.2. and 4.1.3.). The reference ${ }^{87} \mathrm{Sr} /{ }^{86} \mathrm{Sr}$ ratios can be found in Table 5 . It is to be noted that the values for NIST SRM 610 in Table 5 are those from the literature (GEOREM preferred values); ${ }^{29}$ thus, they are not results from the measurements carried out in this work. Most of the stained-glass samples from Stavelot fall into a relatively narrow range of ${ }^{87} \mathrm{Sr} /{ }^{86} \mathrm{Sr}$ isotope ratio values: $0.7098-0.7106$. The only exception is sample ST1278-I1 with a more radiogenic value of 0.718644 . Sample ST1278-I1 also shows a different REE pattern compared to the other glass samples (see Section 4.2.). However, there is some variability in this group as well; most notably, ST1278 Amber and ST1371-V2 have higher values than the other ones. The remaining samples have values close to the seawater signature shared by many locations in (Western) Europe, which makes any attribution difficult.

4.1.2. LA-MC-ICP-MS. The LA-MC-ICP-MS measurement results for the $\mathrm{Sr}$ isotopic analysis of the samples from Stavelot are reported in Table 5. It is generally accepted in the literature that LA-MC-ICP-MS can be used for Sr isotopic analysis, provided that the $\mathrm{Rb} / \mathrm{Sr}$ ratio is sufficiently low (upper limit for $\mathrm{Rb} / \mathrm{Sr}<0.14)^{30}$ and there is no robust approach to correct for $\mathrm{Rb}$ mass discrimination. Under these conditions, a mathematical correction is capable of providing precise and unbiased results. Correction is achieved by subtracting the 


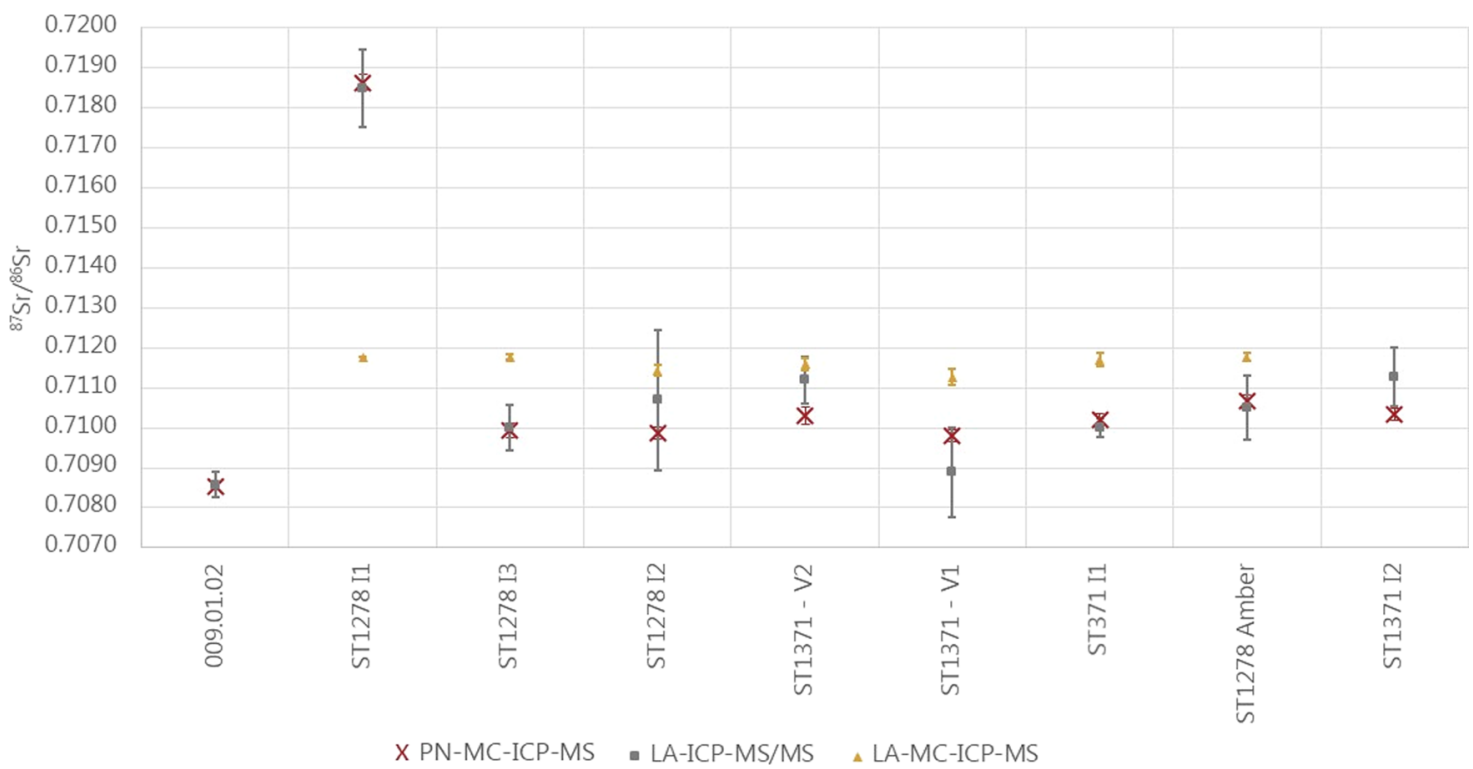

Figure 3. Sr isotope ratio results for glass samples characterized by different $\mathrm{Rb} / \mathrm{Sr}$ ratios and REE concentrations, measured using PN-MC-ICPMS, LA-MC-ICP-MS, and LA-ICP-MS/MS. The error bars indicate the SD.

estimated ${ }^{87} \mathrm{Rb}^{+}$signal from the total signal intensity at a $\mathrm{m} / \mathrm{z}$ ratio of 87 based on the signal intensity at $m / z=85$, the natural ${ }^{85} \mathrm{Rb} /{ }^{87} \mathrm{Rb}$ ratio, and assuming either the same mass discrimination for $\mathrm{Sr}$ and $\mathrm{Rb}$ (Russell exponential law-mass bias correction approach used in this work) or using a modified Russell's exponential law. ${ }^{3,30}$

In this work, the $\mathrm{Sr}$ isotope ratio measurements of stainedglass windows using LA-MC-ICP-MS led to results showing a relatively large bias of $>1.45 \%$ difference compared to the results obtained using PN-MC-ICP-MS. However, there is no linear relation between the increase in the $\mathrm{Rb}$ content (in $\mu \mathrm{g} /$ g) and the signal intensity at a $m / z$ ratio of 85 , as illustrated in Figure 2a. Because ${ }^{85} \mathrm{Rb}$ is the main isotope of $\mathrm{Rb}(72.17 \%)$, there has to be another factor contributing to the signal intensity at $\mathrm{m} / z=85$. It has been documented before that doubly charged REE ions can contribute to the signal intensity at $m / z=85 .^{3,13,30}$ Therefore, the influence of the Er (Figure $2 \mathrm{a})$ and $\mathrm{Yb}$ (Figure $2 \mathrm{~b}$ ) concentrations on the signal intensities at $m / z 85$ and 88 , respectively, was also included in the graph. Based on Figure $2 a, b$, it is difficult to say whether the Er and $\mathrm{Yb}$ concentrations exhibited a significant influence on the signal intensity at $m / z=85$ and 88 . This is, at least in part, due to the fact that signal intensities were matched between samples. Thus, the amount of material sampled, and hence the concentration of REEs introduced into the mass spectrometer, depends on both the concentration of REEs as well as the laser spot size and frequency. This also explains the discrepancies in the signal intensity at $m / z \quad 88$ as a function of the $\mathrm{Sr}$ concentration, as two samples were measured using different ablation conditions; thus, their signal intensities at $\mathrm{m} / \mathrm{z} 88$ show a deviation from the linearity when compared to other samples. Figure $2 \mathrm{c}$ shows that, for the same $\mathrm{Rb} / \mathrm{Sr}$ ratio, the measurement error (i.e., the difference between the results obtained via PN-MC-ICP-MS and LA-MC-ICP-MS) becomes larger as the REE content increases. The only exception to this observation is sample ST 1278A, which can most likely be explained as a result of the lower Hf content in this sample (3 $\mu \mathrm{g} / \mathrm{g}$ compared to $>20 \mu \mathrm{g} / \mathrm{g}$ in the other samples), as doubly charged ${ }^{196} \mathrm{Hf}^{2+}$ interferes at $\mathrm{m} / z$ 88. This can affect the accuracy of the ${ }^{87} \mathrm{Sr} /{ }^{86} \mathrm{Sr}$ isotope ratios, as the ${ }^{88} \mathrm{Sr} /{ }^{86} \mathrm{Sr}$ ratio is used for the mass bias correction of the ${ }^{87} \mathrm{Sr} /{ }^{86} \mathrm{Sr}$ ratio (internal correction). Thus, the absence of $\mathrm{Hf}$ interference might lead to better results than expected on the basis of comparison to other samples.

This experiment thus shows that LA-MC-ICP-MS is not suitable for the $\mathrm{Sr}$ isotopic analysis of samples with elevated $\mathrm{Rb} / \mathrm{Sr}$ ratios and indicates additional nonnegligible bias induced by doubly charged REE ions, especially those of $\mathrm{Yb}$, $\mathrm{Er}$, and Hf, even when operating the instrument in a medium mass resolution. This is in contrast to what was observed in earlier research. ${ }^{3}$ A recent work of Yim et al. confirmed that the problem with high $\mathrm{Rb} / \mathrm{Sr}$ samples can be linked with the assumption that both $\mathrm{Rb}$ and $\mathrm{Sr}$ display the same behavior, and thus the same isotope fractionation. The authors suggested the determination of $\beta \mathrm{Rb}$ using sample standard bracketing and natural abundance and concluded that precise and unbiased $\mathrm{Sr}$ isotope ratio results can be achieved if there is a robust approach to correct for $\mathrm{Rb}$ mass discrimination. ${ }^{18}$

4.1.3. LA-ICP-MS/MS. The results obtained using LA-ICPMS/MS are reported in Table 5. The uncertainty in the ${ }^{87} \mathrm{Sr} /{ }^{86} \mathrm{Sr}$ isotope ratio is always on the fourth decimal number.

In Figure 3, the results from PN-MC-ICP-MS, LA-MC-ICPMS, and LA-ICP-MS/MS are plotted together for comparison. On the one hand, this figure shows that the LA-ICP-MS/MS results are often equal within the experimental uncertainty to the PN-MC-ICP-MS results but that the uncertainty is much larger. This is not surprising as the isotope ratio precision of quadrupole-based ICP-MS instrumentation is rather modest compared to that of MC-ICP-MS instrumentation, as a result of the presence of a single detector only, allowing the monitoring of only one single signal at any given time. ${ }^{32}$ On the other hand, the LA-MC-ICP-MS results are in all cases, except for ST $1278 \mathrm{I} 1$, higher than the corresponding result obtained by PN-MC-ICP-MS.

There is no correlation between the $\mathrm{Rb}$ to $\mathrm{Sr}$ ratio and the error, thus indicating that the use of chemical resolution and $\mathrm{CH}_{3} \mathrm{~F}$ gas in a mass-shift approach (monitoring the $\mathrm{SrF}^{+}$ reaction production ion) successfully overcomes the isobaric 
Table 6. Elemental Composition of the Samples from Stavelot, as Obtained by the LA-ICP-MS Analysis; All Values Are Reported in $\mu \mathrm{g} / \mathrm{g}$, the Reported Uncertainty Corresponds to 2 Times the Standard Deviation of the Replicate Measurements (2 SD).

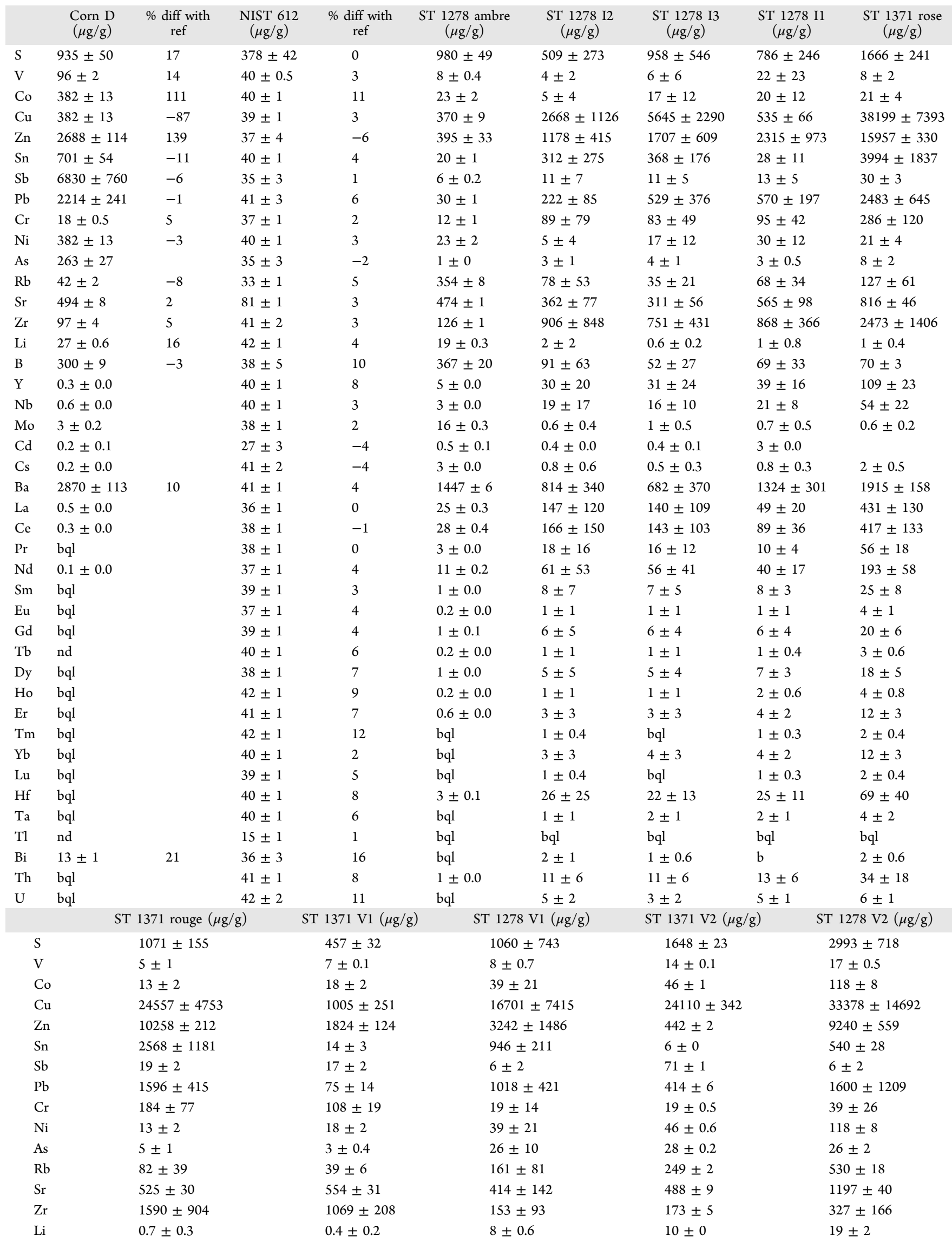


Table 6. continued

\begin{tabular}{|c|c|c|c|c|c|}
\hline & ST 1371 rouge $(\mu \mathrm{g} / \mathrm{g})$ & ST $1371 \mathrm{~V} 1(\mu \mathrm{g} / \mathrm{g})$ & ST $1278 \mathrm{~V} 1(\mu \mathrm{g} / \mathrm{g})$ & ST $1371 \mathrm{~V} 2(\mu \mathrm{g} / \mathrm{g})$ & ST $1278 \mathrm{~V} 2(\mu \mathrm{g} / \mathrm{g})$ \\
\hline B & $45 \pm 2$ & $44 \pm 3$ & $210 \pm 18$ & $315 \pm 3$ & $472 \pm 12$ \\
\hline $\mathrm{Y}$ & $70 \pm 15$ & $40 \pm 8$ & $7 \pm 5$ & $7 \pm 0.2$ & $17 \pm 8$ \\
\hline $\mathrm{Nb}$ & $35 \pm 14$ & $23 \pm 4$ & $4 \pm 3$ & $4 \pm 0$ & $9 \pm 5$ \\
\hline Mo & $0.4 \pm 0.1$ & $0.7 \pm 0.0$ & $2 \pm 1$ & $5 \pm 0.1$ & $2 \pm 0.1$ \\
\hline $\mathrm{Cd}$ & & $0.4 \pm 0.0$ & $2 \pm 3$ & $0.3 \pm 0.1$ & $3 \pm 5$ \\
\hline Cs & $1 \pm 0.3$ & $0.6 \pm 0.1$ & $0.8 \pm 0.1$ & $1 \pm 0.0$ & $2 \pm 0.2$ \\
\hline $\mathrm{Ba}$ & $1231 \pm 102$ & $1158 \pm 149$ & $1733 \pm 1807$ & $1644 \pm 25$ & $8227 \pm 531$ \\
\hline $\mathrm{La}$ & $277 \pm 83$ & $162 \pm 29$ & $33 \pm 20$ & $32 \pm 0.7$ & $77 \pm 31$ \\
\hline $\mathrm{Ce}$ & $268 \pm 86$ & $190 \pm 34$ & $34 \pm 21$ & $33 \pm 0.5$ & $78 \pm 35$ \\
\hline $\operatorname{Pr}$ & $36 \pm 12$ & $22 \pm 4$ & $4 \pm 3$ & $4 \pm 0.1$ & $10 \pm 5$ \\
\hline $\mathrm{Nd}$ & $124 \pm 37$ & $75 \pm 14$ & $15 \pm 9$ & $14 \pm 0.4$ & $34 \pm 14$ \\
\hline $\mathrm{Sm}$ & $16 \pm 5$ & $10 \pm 2$ & $2 \pm 1$ & $2 \pm 0.1$ & $5 \pm 2$ \\
\hline $\mathrm{Eu}$ & $3 \pm 0.7$ & $2 \pm 0.2$ & bql & bql & bql \\
\hline Gd & $13 \pm 4$ & $8 \pm 1$ & $1 \pm 1$ & $1 \pm 0.0$ & $3 \pm 1.5$ \\
\hline $\mathrm{Tb}$ & $2 \pm 0.4$ & $1 \pm 0.2$ & bql & bql & bql \\
\hline Dy & $12 \pm 3$ & $7 \pm 1$ & $1 \pm 1$ & $1 \pm 0.0$ & $3 \pm 1$ \\
\hline Ho & $3 \pm 0.5$ & $1.5 \pm 0.3$ & $\mathrm{bql}$ & bql & $\mathrm{bql}$ \\
\hline Er & $7 \pm 2$ & $5 \pm 1$ & $1 \pm 1$ & $1 \pm 0.0$ & $2 \pm 0.7$ \\
\hline $\mathrm{Tm}$ & $1 \pm 0.3$ & $1 \pm 0.1$ & $\mathrm{bql}$ & $\mathrm{bql}$ & $\mathrm{bql}$ \\
\hline $\mathrm{Yb}$ & $8 \pm 2$ & $5 \pm 1$ & $1 \pm 0.5$ & $1 \pm 0.1$ & $2 \pm 1$ \\
\hline $\mathrm{Lu}$ & $1 \pm 0.3$ & $1 \pm 0.1$ & $\mathrm{bql}$ & $\mathrm{bql}$ & bql \\
\hline $\mathrm{Hf}$ & $45 \pm 26$ & $29 \pm 5$ & $5 \pm 3$ & $5 \pm 0.1$ & $9 \pm 4$ \\
\hline $\mathrm{Ta}$ & $3 \pm 1$ & $2 \pm 0.3$ & bql & bql & bql \\
\hline $\mathrm{Tl}$ & bql & bql & bql & bql & bql \\
\hline $\mathrm{Bi}$ & $1 \pm 0.4$ & bql & bql & $9 \pm 0.1$ & bql \\
\hline Th & $22 \pm 11.4$ & $15 \pm 3$ & $2 \pm 1$ & $2 \pm 0.1$ & $5 \pm 2$ \\
\hline $\mathrm{U}$ & $4 \pm 1$ & $4 \pm 0.5$ & $\mathrm{bql}$ & $\mathrm{bql}$ & $1 \pm 0.5$ \\
\hline
\end{tabular}

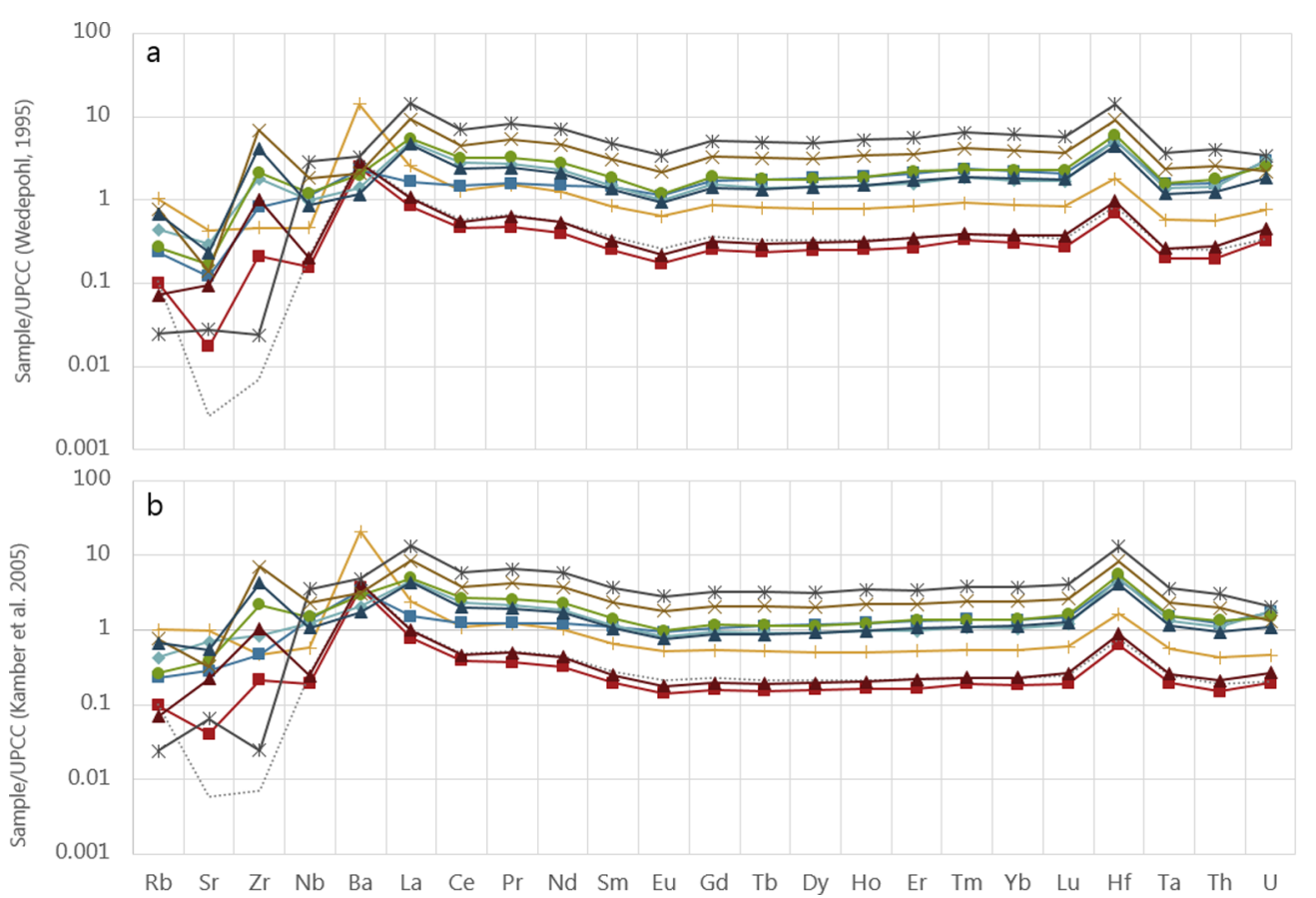

Figure 4. Trace and REE patterns of the glass samples from Stavelot. a: REE concentration normalized to upper continental crust concentrations according to Wedepohl (1995), ${ }^{35}$ b: REE concentration normalized to upper continental crust concentrations according to Kamber et al. (2005). ${ }^{37}$

overlap of ${ }^{87} \mathrm{Rb}$ and ${ }^{87} \mathrm{Sr}$. As an example, sample ST1371V1 has a $\mathrm{Rb} / \mathrm{Sr}$ ratio of 0.07 and a higher error than some of the results for NIST 610 with $\mathrm{Rb} / \mathrm{Sr}=0.83$.

As shown above, the presence of some REEs can lead to interference (double-charged ions) and bias on the isotope ratio data in the case of LA-MC-ICP-MS operated in medium resolution. Although the REE concentrations of the samples are high, their influence on the LA-ICP-MS/MS results is highly improbable. For this to happen, doubly charged REE ions should pass the first quadrupole mass filter (Q1). Subsequently, the double-charge ions should react with two $\mathrm{CH}_{3} \mathrm{~F}$ molecules to form a $\mathrm{REE}-\mathrm{F}_{2}{ }^{2+}$ reaction product ion 
which would then pass through the second quadrupole mass filter (Q2). Statistically, this is not likely to occur, yet it should be noted that $\mathrm{Yb}^{+}+\mathrm{CH}_{3} \mathrm{~F}$ will yield $\mathrm{YbF}^{+}$as is the case for $\mathrm{Sr}$, but not Er. ${ }^{33,34}$ The conditions in both studies and models were very different from our settings, although in theory, at least $\mathrm{YbF}^{+}$can be formed, and the presence of $\mathrm{Yb}$ in the reaction cell is unlikely. Furthermore, no direct link between the error and REE concentration was observed; thus, REEs are unlikely to have biased the LA-ICP-MS/MS results. The increased error for some measurements might be attributed to some unexpected changes in the frequency of the LA system during the measurement session, leading to lower sampling, and hence fewer counts and higher uncertainties.

4.2. Trace and REE Analysis. The minor and trace elemental compositions of the samples from Stavelot are reported in Table 6. Results for reference materials NIST SRM 612 and Corning D are also included for QA/QC of the analytical method. Furthermore, the differences (expressed in $\%)$ between the reference values and the measurement results are also shown. For NIST SRM 612, the difference is smaller than $10 \%$ for almost all elements. The only exceptions are Co, $\mathrm{Tm}, \mathrm{Bi}$, and $\mathrm{U}$. In the case of Corning $\mathrm{D}$, the discrepancies are larger, particularly for $\mathrm{Cu}, \mathrm{Co}$, and $\mathrm{Zn}$; the reasons for these discrepancies are unclear. However, these deviations have no consequences for the present discussion, as those elements were already measured in the original PIXE-PIGE analysis.

In order to visualize trace and REE compositions, the most common approach is to plot them against the average bulk composition of the earth's continental crust. Over time, a number of different baselines have been produced and used for this purpose. ${ }^{35-37}$ Originally, in glass studies, the values reported by Wedepohl $(1995)^{35}$ were used, while more recently, ${ }^{36,37}$ the MUQ (Mud of Queensland) values reported by Kamber et al. $(2005)^{37}$ have been preferred. There are two reasons for preferring these values: (1) they are the most recent ones and (2) they are based on the average of the measurements of the crust, whereas both Wedepohl $(1995)^{35}$ and McLennan et al. $(2001)^{36}$ based their bulk compositions on the measurements of the upper continental crust only combined with modeling/calculations based on a granodiorite composition. To facilitate the comparison of our data with both older and more recent publications, the trace and REE element patterns are plotted against both the Wedepohl $(1995)^{35}$ and Kamber et al. (2004) ${ }^{37}$ values. Comparison to the Wedepohl $(1995)^{35}$ data is especially important, as the earliest studies of REE compositions and patterns of medieval wood ash glass relied on this and have informed much of our understanding of this technology. ${ }^{38}$

In Figure 4, some trace elements ( $\mathrm{Rb}$ to $\mathrm{U}$ ) and REEs, following common practice in archeological glass studies and allowing for comparison with the literature. Samples ST1278V1 and ST1278A plot on top of each other (Figure 4).

It can be noted that most samples are enriched in REEs compared to the earth's crust. Most samples exhibit the same pattern with an enrichment of light REEs (LREEs), particularly $\mathrm{La}$ and $\mathrm{Pr}$ and a negative $\mathrm{Eu}$ anomaly. Both a relative enrichment of LREEs and an Eu anomaly have been associated to medieval wood ash in previous studies. ${ }^{2}$ However, in most other studies, the REEs were still depleted compared to the crust (all relative concentrations plotted below 0.5 ), ${ }^{2,38}$ the only exception being La-Nd in two samples.

All the glass samples have the same overall pattern (even if the absolute concentration of the REEs is different), with the only exception being sample ST1278I1, which is also enriched in $\mathrm{Mn}$ and $\mathrm{Sr}$ compared to other glasses. The red and pink glasses contain the highest REE concentrations, whereas the amber and colorless glasses have the lowest REE contents (close to the values reported by Wedepohl et al. in 2011), ${ }^{2}$ and the green glasses have concentrations between the red/pink and colorless values. The enrichment in LREEs can be attributed to elevated monazite contents in the silica source, which is not completely unexpected if these were sourced locally (Wedepohl and Simon, 2010). ${ }^{39}$

Another proxy used for characterizing the silica source is the $\mathrm{Ce} / \mathrm{La}$ ratio. This ratio is close to $1(0.967-1.02)$ for most of the samples, that is, the Ce and La contents are almost equal. It has been reported that these REEs enter the glass through monazites; in this case, equal proportions of $\mathrm{La}$ and $\mathrm{Ce}$ monazite. There are three exceptions in which the Ce content is higher than the La content: ST1278A (1.09), ST1371V1 (1.17), and finally ST1278I1 (1.80). Ce/La $=1.8$ was found in sands from the Syro-Palestinian coast, and glasses from Cyprus made with this glass are also characterized by a relative enrichment of REE compared to the continental crust. ${ }^{40}$ As it was already shown that ST1278I1 has a very different REE pattern compared to other glasses, it would be tempting to say that this glass might be made from recycled Syro-Palestinian glass. ${ }^{40}$ However, this is highly unlikely as it has less than $1 \%$ $\mathrm{m} / \mathrm{m} \mathrm{Na}_{2} \mathrm{O}^{2,40}$ Therefore, the only conclusion that can be drawn for now is that this particular glass sample was made with sand from a different source. It should also be noted that, in the original publication, elevated $\mathrm{Ba}$ contents were reported for sample ST1278I1 $(0.6 \% \mathrm{~m} / \mathrm{m})$, but this result was not confirmed by the LA-ICP-MS analysis. This is not because of the calibration or the measurement, as ST1278V2 contains $0.56 \% \mathrm{~m} / \mathrm{m} \mathrm{BaO}$ according to Van Wersch et al., ${ }^{1}$ and it was found to contain $8830 \pm 530 \mu \mathrm{g} / \mathrm{g} \mathrm{Ba}(0.92 \% \mathrm{~m} / \mathrm{m} \mathrm{BaO})$ in this study. It is unclear what the source of the discrepancy is for ST1278I1, maybe that locally Ba was enriched or depleted where the LA-ICP-MS was performed. Because LA-ICP-MS only samples a small area (with spot sizes of $100 \mu \mathrm{m}$ ), in PIXE/PIGE, the beam is $1 \mathrm{~mm}$ in diameter.

\section{ARCHEOLOGICAL INTERPRETATION}

5.1. Ash Source. The narrow range of the ${ }^{87} \mathrm{Sr} /{ }^{86} \mathrm{Sr}$ isotope ratio values within which most samples fall (0.7098-0.7106) indicates that they were most likely produced using ashes of the same provenance. There is some variability in this group as well; most notably, ST1278 Amber and ST1371-V2 have higher values than the other ones. The remaining samples have values close to the seawater signature shared by many locations in (Western) Europe, which makes any attribution difficult. The variation in the concentration of ash-related elements (e.g., P, K, and $\mathrm{Mn}$ ) can be attributed to either different pretreatments of the ash or differences in the felling season or part of the tree used for ashing. More detailed analysis on locally available ashes might help answer this question.

Sample ST1278-I1 has a different REE pattern compared to the other glass samples and a more radiogenic value of 0.718644 . For ST1278, further possible source of REE, and possibly $\mathrm{Sr}$, is to be considered: $\mathrm{Mn}$ added to decolor it.

As far as possible comparisons are concerned, the only available Sr isotope ratio data for the Stavelot-Venn Massif are from Romer et al. (2011). ${ }^{41}$ They determined the whole rock $\mathrm{Sr}$ isotopic signatures of $\mathrm{Mn}$-bearing coticules, a type of slate that crops out close to Vielsalm and reported an ${ }^{87} \mathrm{Sr} /{ }^{86} \mathrm{Sr}$ 
isotope ratio of $0.721957 \pm 8$ for these coticules. ${ }^{41}$ This value is far more radiogenic than those for our samples. However, these $\mathrm{Sr}$ isotope ratio results are those from the whole rock analysis and may not reflect bioavailable $\mathrm{Sr}^{41}$ Alternatively, if it does correspond to the bioavailable $\mathrm{Sr}$, then, the trees that grow on this formation may not be the source of the ash used for producing the glass. Until we receive data from the CRUMBEL project (EOS project number 30999782, funded by the Research Foundation Flanders), which aims at mapping bioavailable $\mathrm{Sr}$ across several locations in Belgium, the origin of the ash cannot be further constrained.

5.2. Silica Source. The elevated REE concentrations indicate a silica source with similarly high REE contents. As explained in the SI, the Stavelot-Venn Massif is known for its relative richness in REE, especially $\mathrm{La}$, for which the concentration is also enriched in the glasses (Table 6). Dekoninck et al. (2019) provide a study of the Stavelot Massif with geochemical data on many outcrops. ${ }^{42}$ One of their observations is that the coticules are characterized by a positive $\mathrm{Eu}$ anomaly (i.e., in contrast to what was observed in the Stavelot samples). The Mn-ore-bearing carbonates on the other hand have a positive Ce anomaly. In general, the REE patterns Dekoninck et al. (2019) found are different from those found in the Stavelot samples, and far lower $\mathrm{Hf}$ concentrations are present in the coticules. Sample 16Meu33 (a slate) is the only exception, as it has a strong negative Eu anomaly and elevated Hf contents. ${ }^{42}$ It is unlikely that slates are ground to provide silica for glass making (the high $\mathrm{Fe}$ and $\mathrm{Mn}$ contents would lead to dark green or black glass). However, this shows that such patterns can be found in this area. Unfortunately, no other sediments were studied in that study.

Another strong link with the Stavelot-Venn Massif is provided by the $\mathrm{Ti}$ and $\mathrm{Ba}$ contents that were found for the glass, and both are known to occur in the quartz veins in Stavelot. ${ }^{43}$

\section{CONCLUSIONS}

In this work, new data on REE concentrations and Sr isotopic composition are reported for early medieval wood ash glass from Stavelot. For this purpose, different ICP-MS approaches for obtaining precise and unbiased $\mathrm{Sr}$ isotope ratio measurements have been evaluated.

The influence of $\mathrm{Rb}$ and some REEs on the accuracy of the $\mathrm{Sr}$ isotope ratios obtained by LA-MC-ICP-MS was demonstrated. An increased uncertainty due to the presence of REEs was highlighted in addition to the induced bias.

The analysis of archeological glass from Stavelot by LA-ICPMS/MS and relying on chemical resolution using $\mathrm{CH}_{3} \mathrm{~F}$ to overcome spectral overlap (monitoring of $\mathrm{SrF}^{+}$reaction product ions) was found to be appropriate for the Sr isotopic analysis of glass samples despite high $\mathrm{Rb} / \mathrm{Sr}$ elemental ratios and high REE concentrations. The measurement uncertainty is on the fourth decimal, which is fit-for-purpose for most archeological applications. Self-evidently, the isotope ratio precision achieved by quadrupole-based ICP-MS instrumentation cannot be compared to that obtained with high-precision MC-ICP-MS. However, LA-MC-ICP-MS was not found to be suitable for the $\mathrm{Sr}$ isotopic analysis of high- $\mathrm{Rb}$ glass samples, which can be attributed to the lack of a robust approach to correct for $\mathrm{Rb}$ mass discrimination. PN-MC-ICP-MS can provide highly precise and unbiased $\mathrm{Sr}$ isotope ratio results, but this approach requires complete sample digestion and the chromatographic isolation of Sr from the sample matrix. Thus, when it is not possible to digest part of the sample or for preselecting the samples prior to high-precision MC-ICP-MS analysis, LA-ICP-MS/MS offers a fast and minimally invasive way to determine the $\mathrm{Sr}$ isotopic composition of glass with high $\mathrm{Rb} / \mathrm{Sr}$ elemental ratios and high $\mathrm{REE}$ concentrations, also allowing spatially resolved information to be obtained in a minimally invasive way. As a future option, the laboratory in Bristol, in collaboration with ThermoScientific, has recently developed a prototype of a MC-ICP-MS instrument that combines the use of CRC technology to overcome the spectral overlap and the simultaneous detection traditionally offered by this type of instrumentation, thus providing high precision and unbiased isotope ratio measurements for elements strongly affected by spectral interferences. ${ }^{44}$ The possibilities of this instrumentation have already been demonstrated for $\mathrm{Sr}$ isotopic analysis using $\mathrm{SF}_{6}$ as the $\mathrm{CRC}$ gas to overcome the spectral overlap of ${ }^{87} \mathrm{Rb}$ and ${ }^{87} \mathrm{Sr}$ in a mass-shift approach by monitoring the $\mathrm{SrF}^{+}$reaction product ions, a method similar to the one described in this work. However, this instrument is not yet commercially available, while the cost of this instrumentation also needs to be considered. Hence, LA-ICP-MS/MS still needs to be considered as one of the most suitable options for in situ $\mathrm{Sr}$ isotopic analysis of high- $\mathrm{Rb}$ samples.

The interpretation of the results indicates that the $\mathrm{Sr}$ isotopic signature of the glasses from Stavelot is relatively uniform, with ${ }^{87} \mathrm{Sr} /{ }^{86} \mathrm{Sr}$ ratios ranging from 0.7098 to 0.7106 . Only one sample, ST1278-I1, falls far outside this range $\left({ }^{87} \mathrm{Sr} /{ }^{86} \mathrm{Sr}\right.$ 0.718644). This uniformity suggests that the samples were produced using ash from a single source with either different pretreatments or seasonal fluctuations causing the variability in $\mathrm{K}, \mathrm{P}$, and $\mathrm{Mn}$ concentrations in the glass. The $\mathrm{Sr}$ isotopic signature does not correspond to the whole rock $\mathrm{Sr}$ isotopic composition of the local slates.

Sample ST1278-I1 has a different REE pattern and $\mathrm{Sr}$ isotopic signature compared to the other samples, suggesting that this sample was prepared using different raw materials (both the ash and the sand). Import of wood ash glass is not likely in that period because it is an emerging technique, and the Stavelot site is actually one of the earliest known occurrences. Recycling of natron glass, even if wood ash is added, would yield a relatively high $\mathrm{Na}_{2} \mathrm{O}$ content, and because ST1278-I1 contains less than $1.5 \% \mathrm{~m} / \mathrm{m} \mathrm{Na}_{2} \mathrm{O}$, this is unlikely. For now, the origin of this sample remains an open question.

\section{ASSOCIATED CONTENT}

\section{SI Supporting Information}

The Supporting Information is available free of charge at https://pubs.acs.org/doi/10.1021/acsomega.1c01939.

Short summary of the archeological backdrop as well as an introduction to the studied assemblage (PDF).

\section{AUTHOR INFORMATION}

\section{Corresponding Author}

Alicia Van Ham-Meert - Earth and Environmental Science, Centre for Archaeological Science, KU Leuven, B-3001 Heverlee, Belgium; Analytical, Environmental and Geochemistry, Vrije Universiteit Brussel, B-1050 Elsene, Belgium; (1) orcid.org/0000-0001-6796-3141; Email: alicia.vanhammeert@gmail.com 


\section{Authors}

Eduardo Bolea-Fernandez - Atomic and Mass Spectrometry - A\&MS research group, Department of Chemistry, Ghent University, B-9000 Ghent, Belgium

Joke Belza - Atomic and Mass Spectrometry - A\&MS research group, Department of Chemistry, Ghent University, B-9000 Ghent, Belgium

Dan Bevan - School of Earth Sciences, University of Bristol, Bristol BS8 1RJ, United Kingdom

Klaus Peter Jochum - Department of Climate Geochemistry, Max Planck Institute for Chemistry, 55128 Mainz, Germany

Brigitte Neuray - SPW, AWAP (agence wallone du patrimoine), B-4000 Liège, Belgium

Brigitte Stoll - Department of Climate Geochemistry, Max Planck Institute for Chemistry, 55128 Mainz, Germany

Frank Vanhaecke - Atomic and Mass Spectrometry - A\&MS research group, Department of Chemistry, Ghent University, B-9000 Ghent, Belgium; (1) orcid.org/0000-0002-18843853

Line Van Wersch - UR Art, Archéologie Patrimoine, Université de Liège, B-4000 Liège, Belgium; Faculty of archaeology, Leiden University, 2333 CC Leiden, The Netherlands

Complete contact information is available at:

https://pubs.acs.org/10.1021/acsomega.1c01939

\section{Notes}

The authors declare no competing financial interest.

\section{ACKNOWLEDGMENTS}

The Flemish Research Foundation (FWO-Vlaanderen) is acknowledged for providing the funding for the acquisition of MC-ICP-MS instrumentation in operation at A\&MSUGent (ZW15-02 - G0H6216N). The FWO is also acknowledged for funding project G.0C43.15 on which Alicia Van Ham-Meert was employed while doing this research. Eduardo Bolea-Fernandez also thanks FWO-Vlaanderen for his postdoctoral grant (12ZA320N).

\section{REFERENCES}

(1) Van Wersch, L.; Biron, I.; Neuray, B.; Mathis, F.; Chêne, G.; Strivay, D.; Sapin, S. Early medieval stained-glass window from stavelot (belgium) [Les vitraux alto-médiévaux de Stavelot (Belgique)]. Arch. Androl. 2014, 38, 219-234.

(2) Wedepohl, K. H.; Simon, K.; Kronz, A. The chemical composition including the rare earth elements of the three major glass types of Europe and the orient used in late antiquity and the middle ages. Chem. Erde 2011, 71, 289-296.

(3) Van Ham-Meert, A.; Chernonozhkin, S. M.; Van Malderen, S. J. M.; Van Acker, T.; Vanhaecke, F.; Degryse, P. Assessment of nanosecond laser ablation multi-collector inductively coupled plasmamass spectrometry for $\mathrm{Pb}$ and $\mathrm{Sr}$ isotopic determination in archaeological glass: Mass bias correction strategies and results for Corning glass reference materials. Geostand. Geoanal. Res. 2018, 42, 223-238.

(4) Bolea-Fernandez, E.; Van Malderen, S. J. M.; Balcaen, L.; Resano, M.; Vanhaecke, F. Laser ablation-tandem ICP-mass spectrometry (LA-ICP-MS/MS) for direct Sr isotopic analysis of solid samples with high $\mathrm{Rb} / \mathrm{Sr}$ ratios. J. Anal. At. Spectrom 2016, 31, 464-472.

(5) Bolea-Fernandez, E.; Balcaen, L.; Resano, M.; Vanhaecke, F. Tandem ICP-mass spectrometry for $\mathrm{Sr}$ isotopic analysis without prior $\mathrm{Rb} / \mathrm{Sr}$ separation. J. Anal. At. Spectrom 2016, 31, 303-310.

(6) Stern, W. B.; Gerber, Y. Potassium-calcium glass: New data and experiments. Arch. Androl. 2004, 46, 137-156.
(7) Cílová, Z.; Woitsch, J. Potash - A key raw material of glass batch for bohemian glasses from $14^{\text {th }}-17^{\text {th }}$ centuries? J. Archaeol. Sci. 2012, 39, 371-380.

(8) Maresca, A.; Hyks, J.; Astrup, T. F. Recirculation of biomass ashes onto forest soils: Ash composition, mineralogy and leaching properties. Waste Manag. 2017, 70, 127-138.

(9) Reynolds, A. C.; Betancourt, J. L.; Quade, J.; Patchett, P. J.; Dean, J. S.; Stein, J. ${ }^{87} \mathrm{Sr} /{ }^{86} \mathrm{Sr}$ sourcing of ponderosa pine used in Anasazi great house construction at Chaco Canyon, New Mexico. J. Archaeol. Sci. 2005, 32, 1061-1075.

(10) Henderson, J.; Evans, J.; Barkoudah, Y. The roots of provenance: glass, plants and isotopes in the Islamic middle east. Antiquity 2009, 83, 414-429.

(11) Meek, A.; Henderson, J.; Evans, J. Isotope analysis of English forest glass from the Weald and Staffordshire. J. Anal. At. Spectrom 2012, 27, 786-795.

(12) Ramos, F. C.; Wolff, J. A.; Tollstrup, D. L. Measuring ${ }^{87} \mathrm{Sr} /{ }^{86} \mathrm{Sr}$ variations in minerals and groundmass from basalts using LA-MCICPMS. Chem. Geol. 2004, 211, 135-158.

(13) Woodhead, J.; Swearer, S.; Hergt, J.; Maas, R. In situ Sr-isotope analysis of carbonates by LA-MC-ICP-MS: Interference corrections, high spatial resolution and an example from otolith studies. J. Anal. At. Spectrom 2005, 20, 22-27.

(14) Paton, C.; Woodhead, J. D.; Hergt, J. M.; Phillips, D.; Shee, S. Strontium isotope analysis of kimberlitic groundmass perovskite via LA-MC-ICP-MS. Geostand. Geoanal. Res. 2007, 31, 321-330.

(15) Yang, Y.; Wu, F.; Xie, L.; Chu, Z.; Yang, J. Re-evaluation of interferences of doubly charged ions of heavy rare earth elements on $\mathrm{Sr}$ isotopic analysis using multi-collector inductively coupled plasma mass spectrometry. Spectrochim. Acta, Part B 2014, 97, 118-123.

(16) Balcaen, L.; Bolea-Fernandez, E.; Resano, M.; Vanhaecke, F. Inductively coupled plasma - Tandem mass spectrometry (ICP-MS/ MS): A powerful and universal tool for the interference-free determination of (ultra)trace elements - A tutorial review. Anal. Chim. Acta 2015, 894, 7-19.

(17) Moens, L. J.; Vanhaecke, F.; Bandura, D. R.; Baranov, V. I.; Tanner, S. D. Elimination of isobaric interferences in ICP-MS, using ion-molecule reaction chemistry: $\mathrm{Rb} / \mathrm{Sr}$ age determination of magmatic rocks, a case study. J. Anal. At. Spectrum. 2001, 16, 991994.

(18) Yim, S.-G.; Jung, M.-J.; Jeong, Y.-J.; Kim, Y.; Chang-sik Cheong, $\mathrm{A}$. Mass fractionation of $\mathrm{Rb}$ and $\mathrm{Sr}$ isotopes during laser ablation-multicollector-ICPMS: in situ observation and correction. J. Anal. Sci. Techn. 2021, 12, 10.

(19) Bolea-Fernandez, E.; Balcaen, L.; Resano, M.; Vanhaecke, F. Overcoming spectral overlap: Via inductively coupled plasma-tandem mass spectrometry (ICP-MS/MS). A tutorial review. J. Anal. At. Spectrum. 2017, 32, 1660-1679.

(20) Vanhaecke, F.; Balcaen, L.; Deconinck, I.; De Schrijver, I.; Almeida, C. M.; Moens, L. Mass discrimination in dynamic reaction cell (DRC)-ICP-mass spectrometry. J. Anal. At. Spectrum. 2003, 18, 1060-1065.

(21) Gourgiotis, A.; Ducasse, T.; Barker, E.; Jollivet, P.; Gin, S.; Bassot, S.; Cazala, C. Silicon isotope ratio measurements by inductively coupled plasma tandem mass spectrometry for alteration studies of nuclear waste glasses. Anal. Chem. Acta 2017, 954, 68-76.

(22) Van Ham-Meert, A.; Claeys, P.; Jasim, S.; Overlaet, B.; Yousif, E.; Degryse, P. Plant ash glass from first century CE dibba, U.A.E. Archaeol. and Anthropol. Sci. 2019, 11, 1431-1441.

(23) Neuray, B. Les vitraux découverts dans les fouilles de l'église abbatiale de Stavelot (Belgique). Bull. De l'Assoc. Franç. De l'Archéol. $\mathrm{Du}$ Ver. 1996, 9-15.

(24) Gratuze, B.; Blet-Lemarquand, M.; Barrandon, J. Mass spectrometry with laser sampling: A new tool to characterize archaeological materials. J. Radioanal. Nucl. Chem. 2001, 247, 645656.

(25) Ganio, M.; Latruwe, K.; Brems, D.; Muchez, P.; Vanhaecke, F.; Degryse, $\mathrm{P}$. The $\mathrm{Sr}-\mathrm{Nd}$ isolation procedure for subsequent isotopic analysis using multi-collector ICP-mass spectrometry in the context of 
provenance studies on archaeological glass. J. Anal. At. Spectrom 2012, $27,1335-1341$.

(26) Aramendía, M.; Resano, M.; Vanhaecke, F. Isotope ratio determination by laser ablation-single collector-inductively coupled plasma-mass spectrometry. General capabilities and possibilities for improvement. J. Anal. At. Spectrom 2010, 25, 390-404.

(27) Appelbald, P. K.; Rodushkin, I.; Baxter, D. C. Sources of Uncertainty in Isotope Ratio Measurements by Inductively Coupled Plasma Mass Spectrometry. Anal. Chem. 2001, 73, 2911-2919.

(28) Weis, D.; Kieffer, D.; Maerschalk, C.; Barling, J.; de Jong, J.; Williams, G. A.; et al. High-precision isotopic characterization of USGS reference materials by TIMS and MC-ICP-MS. Geochem. Geophys. Geosyst. 2006, 7, No. Q08006.

(29) Jochum, K. P.; Nohl, U.; Herwig, K.; Lammel, E.; Stoll, B.; Hofmann, A. W. GeoReM: A New Geochemical Database for Reference Materials and Isotopic Standards. Geostand. Geoanal. Res. 2005, 29, 333-338.

(30) Zhang, L.; Ren, Z.; Wu, Y.; Li, N. Strontium isotope measurement of basaltic glasses by laser ablation multiple collector inductively coupled plasma mass spectrometry based on a linear relationship between analytical bias and $\mathrm{Rb} / \mathrm{Sr}$ ratios. Rapid Commun. Mass Spectrom. 2018, 32, 105-112.

(31) Woodhead, J. D.; Hergt, J. M. Strontium, neodymium and lead isotope analyses of NIST glass certified reference materials: SRM 610, 612, 614. Geostand. Newsl. 2001, 25, 261-266.

(32) Vanhaecke, F.; Balcaen, L.; Malinovsky, D. Use of singlecollector and multi-collector ICP-mass spectrometry for isotopic analysis. J. Anal. At. Spectrom 2009, 2009, 863-886.

(33) Dirscherl, R.; Lee, H. U. Laser fluorescence study of ytterbium plus halomethane reactions. J. Chem. Phys. 1980, 73, 3831-3837.

(34) Migdisov, A. A.; Williams-Jones, A. E. Hydrothermal transport and deposition of the rare earth elements by fluorine-bearing aqueous liquids. Miner. Deposita 2014, 49, 987-997.

(35) Wedepohl, H. K. The composition of the continental crust. Geochim. Cosmochim. Acta 1995, 59, 1217-1232.

(36) McLennan, S. M. Relationships between the trace element composition of sedimentary rocks and upper continental crust. Geochem. Geophys. Geosyst. 2001, 2, 109.

(37) Kamber, B. S.; Greig, A.; Collerson, K. D. A new estimate for the composition of weathered young upper continental crust from alluvial sediments, Queensland, Australia. Geochim. Cosmochim. Acta 2005, 69, 1041-1058.

(38) Gliozzo, E.; Lepri, B.; Saguì, L.; Memmi, I. Glass ingots, raw glass chunks, glass wastes and vessels from fifth century $\mathrm{AD}$ Palatine hill (Rome, Italy). Archaeol. and Anthropol. Sci. 2017, 9, 709-725.

(39) Wedepohl, K. H.; Simon, K. The chemical composition of medieval wood ash glass from Central Europe. Chem. Erde-Geochem. 2010, 70, 89-97.

(40) Ceglia, A.; Cosyns, P.; Schibille, N.; Meulebroeck, W. Unravelling provenance and recycling of late antique glass from Cyprus with trace elements. Archaeol. and Anthropol. Sci. 2019, 11, 279-291.

(41) Romer, R. L.; Kirsch, M.; Kroner, U. Geochemical signature of Ordovician Mn-rich sedimentary rocks on the Avalonian shelf. Can. J. Earth Sci. 2011, 48, 703-718.

(42) Dekoninck, A.; Monié, P.; Blockmans, S.; Hatert, F.; Rochez, G.; Yans, J. Genesis and 40Ar/39Ar dating of K-Mn oxides from the Stavelot massif (Ardenne, Belgium): Insights into oligocene to pliocene weathering periods in Western Europe. Ore Geol. Rev. 2019, 115, No. 103191.

(43) Fransolet, A.; Deliens, M. Crandallite and wardite in the quartz veins of the Stavelot massif, Belgium [Crandallite et wardite dans les filons de quartz du Massif de Stavelot, Belgique]. Bull. De l'Institut $R$. Des Sci. Nat. De Belq., Sci. De La Ter. 1997, 67, 189-194.

(44) Bevan, D.; Coath, C. D.; Lewis, J.; Schwieters, J.; Lloyd, N.; Craig, G.; Wehrs, H.; Elliott, T. In situ Rb-Sr dating by collision cell, multicollection inductively-coupled plasma mass-spectrometry with pre-cell mass-filter, (cc-MC-ICP-MS/MS). J Anal At Spectrom 2021, 36, 917. 